\title{
Glutamatergic Preoptic Area Neurons That Express Leptin Receptors Drive Temperature-Dependent Body Weight Homeostasis
}

\author{
Sangho Yu, ${ }^{1}$ Emily Qualls-Creekmore, ${ }^{1}$ Kavon Rezai-Zadeh, ${ }^{1}$ Yanyan Jiang, ${ }^{2}$ Hans-Rudolf Berthoud, ${ }^{3}$ \\ Christopher D. Morrison, ${ }^{4}$ Andrei V. Derbenev, ${ }^{2}$ Andrea Zsombok, ${ }^{2}$ and Heike Münzberg ${ }^{1}$ \\ ${ }^{1}$ Departments of Central Leptin Signaling, ${ }^{3}$ Neurobiology of Nutrition, and ${ }^{4}$ Neurosignaling, Pennington Biomedical Research Center, Louisiana State \\ University System, Baton Rouge, Louisiana 70808, and ${ }^{2}$ Department of Physiology, School of Medicine, Tulane University, New Orleans, Louisiana 70112
}

The preoptic area (POA) regulates body temperature, but is not considered a site for body weight control. A subpopulation of POA neurons express leptin receptors (LepRb ${ }^{\mathrm{POA}}$ neurons) and modulate reproductive function. However, LepRb ${ }^{\mathrm{POA}}$ neurons project to sympathetic premotor neurons that control brown adipose tissue (BAT) thermogenesis, suggesting an additional role in energy homeostasis and body weight regulation. We determined the role of $\mathrm{LepRb}^{\mathrm{POA}}$ neurons in energy homeostasis using $c r e$-dependent viral vectors to selectively activate these neurons and analyzed functional outcomes in mice. We show that LepRb ${ }^{\text {POA }}$ neurons mediate homeostatic adaptations to ambient temperature changes, and their pharmacogenetic activation drives robust suppression of energy expenditure and food intake, which lowers body temperature and body weight. Surprisingly, our data show that hypothermia-inducing LepRb ${ }^{\text {POA }}$ neurons are glutamatergic, while GABAergic POA neurons, originally thought to mediate warm-induced inhibition of sympathetic premotor neurons, have no effect on energy expenditure. Our data suggest a new view into the neurochemical and functional properties of BAT-related POA circuits and highlight their additional role in modulating food intake and body weight.

Key words: body temperature; body weight; DREADD; energy expenditure; food intake; thermoregulation

Significance Statement

Brown adipose tissue (BAT)-induced thermogenesis is a promising therapeutic target to treat obesity and metabolic diseases. The preoptic area (POA) controls body temperature by modulating BAT activity, but its role in body weight homeostasis has not been addressed. LepRb ${ }^{\mathrm{POA}}$ neurons are BAT-related neurons and we show that they are sufficient to inhibit energy expenditure. We further show that LepRb ${ }^{\mathrm{POA}}$ neurons modulate food intake and body weight, which is mediated by temperature-dependent homeostatic responses. We further found that LepRb ${ }^{\mathrm{POA}}$ neurons are stimulatory glutamatergic neurons, contrary to prevalent models, providing a new view on thermoregulatory neural circuits. In summary, our study significantly expands our current understanding of central circuits and mechanisms that modulate energy homeostasis.

\section{Introduction}

Adult animals and humans maintain their body weight at relatively constant levels through the intricate balance between food

Received Jan. 20, 2016; revised March 18, 2016; accepted March 21, 2016.

Author contributions: S.Y. and H.M. designed research; S.Y., E.Q.-C., K.R.-Z., Y.J., and H.M. performed research; S.Y., E.Q.-C., K.R.-Z., Y.J., H.-R.B., C.D.M., A.V.D., A.Z., and H.M. analyzed data; S.Y., E.Q.-C., K.R.-Z., Y.J., H.-R.B., C.D.M., and H.M. wrote the paper.

This work was supported by American Heart Association (AHA) and National Institutes of Health (NIH) Grants AHA053298N, NIH P/F DK020572-30, and NIH R01-DK092587 to H.M.; and NIH P20 GM103528 and NIH P/F NORC \#2P30-DK072476 to H.M. and S.Y. This work used the facilities of the Cell Biology and Bioimaging Core, supported in part by Centers of Biomedical Research Excellence (Grant NIH P20-GM103528) and Clinical Nutrition Research Unit (Grant NIH 1P30-DK072476) center grants from the National Institutes of Health. Partial support was provided through the Animal Phenotyping Core supported through National Institute of Diabetes and Digestive and Kidney Diseases Nutrition Obesity Research Centers Grant \#2P30 DK072476 (entitled Nutritional Programming: Environ- intake and energy expenditure, which is largely regulated by the hypothalamus and brainstem (Gao and Horvath, 2007; Rosenbaum and Leibel, 2010). Leptin promotes a negative energy balance and weight loss by suppressing food intake and enhancing energy expenditure through leptin receptor (LepRb)-expressing neurons in the brain, while the absence of leptin action promotes

mental and Molecular Interactions) at the Pennington Biomedical Research (enter. H.R.B. was partly supported by NIH DK047348, C.D.M. by NIH DK105032 and DK081563, E.Q.C. by NIH T32-DK064585, and K.R.Z. by NIH F32-097896 The authors declare no competing financial interests.

Correspondence should be addressed to either Heike Münzberg, PhD, or Sangho Yu, PhD, Pennington Biomedical Research Center, Louisiana State University System, 6400 Perkins Rd., Baton Rouge, LA 70808 E-mail: Heike.Munzberg@pbrc.edu or Sangho.Yu@pbrc.edu.

DOI:10.1523/JNEUROSCI.0213-16.2016

Copyright $\odot 2016$ the authors $\quad 0270-6474 / 16 / 365034-13 \$ 15.00 / 0$ 
a positive energy balance and weight gain (Münzberg and Morrison, 2015). Leptin increases energy expenditure by stimulating brown adipose tissue (BAT) thermogenesis, and leptin-deficient mice show hypothermia and cold intolerance due to reduced BAT activity (Trayhurn et al., 1977; Haynes et al., 1997). Leptin action in the dorsomedial hypothalamus/dorsal hypothalamic area (DMH/DHA) regulates BAT thermogenesis and body weight by enhancing BAT sympathetic nerve activity (SNA; Enriori et al., 2011; Rezai-Zadeh et al., 2014). Another population of BAT-related LepRb neurons is found in the preoptic area (POA; Zhang et al., 2011). However, the role of these LepRb ${ }^{\text {POA }}$ neurons in energy homeostasis and body weight control is unknown.

The POA responds to changes in ambient temperature. This modulates the SNA in BAT, a heat generating tissue that regulates core temperature (Nakamura, 2011). Previous studies have suggested that cold-inhibited and warm-activated GABAergic POA neurons innervate BAT-related DMH/DHA and rostral raphe pallidus (rRPa) neurons (Nakamura et al., 2002, 2005, 2009; Yoshida et al., 2009). Indeed, cold exposure potently stimulates while warm/thermoneutral exposure strongly inhibits BAT thermogenesis. These robust changes in energy expenditure typically do not affect body weight due to simultaneous stimulation or inhibition of food intake during cold or warm exposure, respectively (Ravussin et al., 2014; Xiao et al., 2015). This type of adaptation is in contrast to the negative energy balance promoted by leptin that increases energy expenditure, while decreasing food intake. In fact, leptin's involvement in POA-mediated energy homeostasis is unlikely because the selective deletion of LepRb in the POA disrupts reproductive function in female mice without affecting body weight (Bellefontaine et al., 2014).

However, the POA's well known function in BAT SNA control and the fact that LepRb ${ }^{\mathrm{POA}}$ neurons multisynaptically innervate BAT through the DMH/DHA and the rRPa (Zhang et al., 2011) strongly suggest that LepRb ${ }^{\mathrm{POA}}$ neurons affect BAT thermogenesis, but may be independent of leptin. Also, DMH/DHA LepRb neurons modulate energy expenditure and body weight (RezaiZadeh et al., 2014), further indicating that BAT-connected LepRb ${ }^{\mathrm{POA}}$ neurons may similarly regulate body weight.

Employing pharmacogenetic activation of LepRb, glutamatergic, or GABAergic POA neurons, we confirmed that LepRb ${ }^{\text {POA }}$ neurons robustly block BAT thermogenesis, resulting in decreased core temperature. Furthermore, we uncovered their additional role in suppressing food intake, which caused significant body weight loss. In contrast to previous reports, we found no evidence that GABAergic POA neurons regulate BAT thermogenesis. To the contrary, we show compelling evidence that glutamatergic LepRb ${ }^{\mathrm{POA}}$ neurons mediate adaptive changes in food intake and energy expenditure in response to ambient temperature changes. Our data suggest a new view of the neurochemical and functional properties of BAT-related POA circuits and highlight their additional role in modulating temperature-dependent food intake and body weight homeostasis.

\section{Materials and Methods}

Animals. All experiments were approved by the Institutional Animal Care and Use Committee. Mice were housed at room temperature (RT) with a $12 \mathrm{~h}$ light/dark cycle. Laboratory rodent diet (\#5001, LabDiet) and water were available ad libitum unless otherwise stated. LepR $b^{E G F P}$ and $L e p R b^{C r e}$ mice (kindly provided by Dr. Martin G. Myers, Jr., University of Michigan; Leshan et al., 2006, 2010); and Vglut2 ${ }^{\text {Cre }}$, Vglut $^{\text {EYFP }}$, Vgat ${ }^{\text {Cre }}$, and $V g a t^{E Y F P}$ mice (generously provided by Dr. Bradford B. Lowell, Beth Israel Deaconess Medical Center and Harvard Medical School; Vong et al., 2011) were obtained from in-house breeding colonies. Only male mice were used for studies of temperature-dependent cFos induction and warm-induced change in energy expenditure and food intake (see Fig. 5). All other experiments were conducted with both sexes and no sex differences were observed.

Stereotaxic surgery. Stereotaxic viral injection adenoassociated virus (AAV) was performed as previously described (Rezai-Zadeh et al., 2014). AAV5-hSyn-DIO-mCherry (control) and AAV5-hSyn-DIO-hM3DqmCherry ([DREADD-Gq (Gq-coupled Designer Receptor Exclusively Activated by Designer Drug)] were made available by Dr. Bryan Roth and obtained through the vector core of the University of North Carolina at Chapel Hill. Deeply anesthetized 8-10-week-old LepRb ${ }^{\mathrm{Cre}}$, Vglut2 ${ }^{\mathrm{Cre}}$, or Vgat ${ }^{\text {Cre }}$ mice were placed on a stereotaxic alignment system (\#1900, David Kopf Instruments) to facilitate accurate, bilateral viral injections into the POA (anteroposterior, $0.55 \mathrm{~mm}$; mediolateral, $\pm 0.4 \mathrm{~mm}$; dorsoventral, $-5.2 \mathrm{~mm} ; 200-400 \mathrm{nl}$ total, $20 \mathrm{nl} / 30 \mathrm{~s}$ ) according to the Paxinos mouse brain atlas (Paxinos and Franklin, 2004). Guide cannula and injector remained in place for $5 \mathrm{~min}$ before removal to prevent backflow, and skull and incision was closed with bone wax (Lukens \#901, Medline Industries) and wound clips (\#203-1000, CellPoint Scientific). Mice were single-housed for experiments $2-3$ weeks later. Only data from mice with correctly targeted virus injections were used for analysis. DREADD-Gqinjected mice without proper viral expression in the POA failed to show clozapine $\mathrm{N}$-oxide (CNO; \#C0832, Sigma-Aldrich)-induced changes in core temperature or energy expenditure. Finally, control or DREADDGq-injected mice received a saline or CNO (0.5 or $1.5 \mathrm{mg} / \mathrm{kg}$, i.p.) $2-3 \mathrm{~h}$ before perfusions. Then brains were harvested and analyzed to confirm $\mathrm{CNO}$-induced neuronal activation.

Rectal temperature measurement. Rectal temperature was measured with a thermal probe (\#227-193, ThermoWorks) every 20 min for 100 min following saline or $\mathrm{CNO}$ injections.

Metabolic studies. Energy expenditure, locomotor activity, and respiratory exchange ratio (RER) were measured in a Comprehensive Laboratory Animal Monitoring System (CLAMS; Columbus Instruments) or a TSE system (TSE Systems). In the TSE system, food intake data were also collected. Mice were acclimated for $\geq 3 \mathrm{~d}$ before collection of experimental data.

Data were collected by the TSE system in response to consecutive treatments with saline or different CNO doses $(0.025,0.05,0.1,0.2,0.4$, 0.8 , and $1.6 \mathrm{mg} / \mathrm{kg}$, i.p.) right before the dark cycle every other day. Metabolic measurements (20 min intervals) were obtained at RT and $6 \mathrm{~h}$ averages were compared between saline (baseline) and CNO injections to calculate $\Delta \mathrm{VO}_{2}, \Delta$ food intake, $\Delta$ activity, and $\Delta \mathrm{RER}$.

For warm $\left(30^{\circ} \mathrm{C}\right)$ exposure-induced changes in energy expenditure and food intake, data were collected by the TSE system in male mice $\left(22^{\circ} \mathrm{C}, n=6 ; 30^{\circ} \mathrm{C}, n=6\right.$; ), and $3 \mathrm{~d}$ mean values were normalized by body weight.

For measurements during changing ambient temperatures $\left(L e p R b^{P O A}\right.$, Vglut2 ${ }^{P O A}$, and Vgat ${ }^{P O A}$ DREADD-Gq mice, $n=4$ for each group), mice were initially kept at RT $\left(22^{\circ} \mathrm{C}\right)$. At circadian time (CT) 4 , ambient temperature was changed to $30^{\circ} \mathrm{C}, 10^{\circ} \mathrm{C}$, or maintained at RT. At CT5, mice received consecutive treatments with saline or $\mathrm{CNO}(0.5 \mathrm{mg} / \mathrm{kg}$, i.p. $)$ injections and, at CT12, ambient temperature was returned to RT (see Fig. $6 \mathrm{~A}$ ). $\Delta \mathrm{VO}_{2}$, $\Delta$ activity, and $\triangle$ RER were calculated from baselines ( $1 \mathrm{~h}$ mean before the onset of ambient temperature change) and $4 \mathrm{~h}$ means after injections, and data were compared between saline and CNO injections.

To test the interaction between LepRb ${ }^{\text {POA }}$ neurons and $\beta 3$ adrenergic receptor $(\beta 3 \mathrm{AR})$ signaling, $\mathrm{VO}_{2}$, locomotor activity, and RER were measured in a group of LepR $R b^{P O A}$ DREADD-Gq mice $(n=4)$ by CLAMS at RT. After $3 \mathrm{~d}$ of acclimation, saline, CNO $(0.5 \mathrm{mg} / \mathrm{kg}$, i.p.), CL316,243 (1.0 mg/kg, i.p.), or CNO + CL316,243 was injected at CT5 on 4 consecutive days.

The effect of chronic CNO injection on body weight was tested by injecting saline $(3 \mathrm{~d})$ or $\mathrm{CNO}(6 \mathrm{~d} ; 0.3 \mathrm{mg} / \mathrm{kg}$, i.p.) twice daily, once at CT2.5 and another at CT11 in $L e p R b^{P O A}$ control $(n=5)$ and $L e p R b^{P O A}$ DREADD-Gq $(n=5)$ mice while they were housed in the TSE system at RT (see Fig. $3 A$ ). Body weight was measured every day just before a morning injection with ad libitum food and water. $\mathrm{VO}_{2}$, locomotor activity, RER, and food intake were monitored every $25 \mathrm{~min}$.

Restricted feeding. To measure pharmacogenetically induced foodintake changes, a group of $L e p R b^{P O A}$ control $(n=5)$ and $L e p R b^{P O A}$ 
A

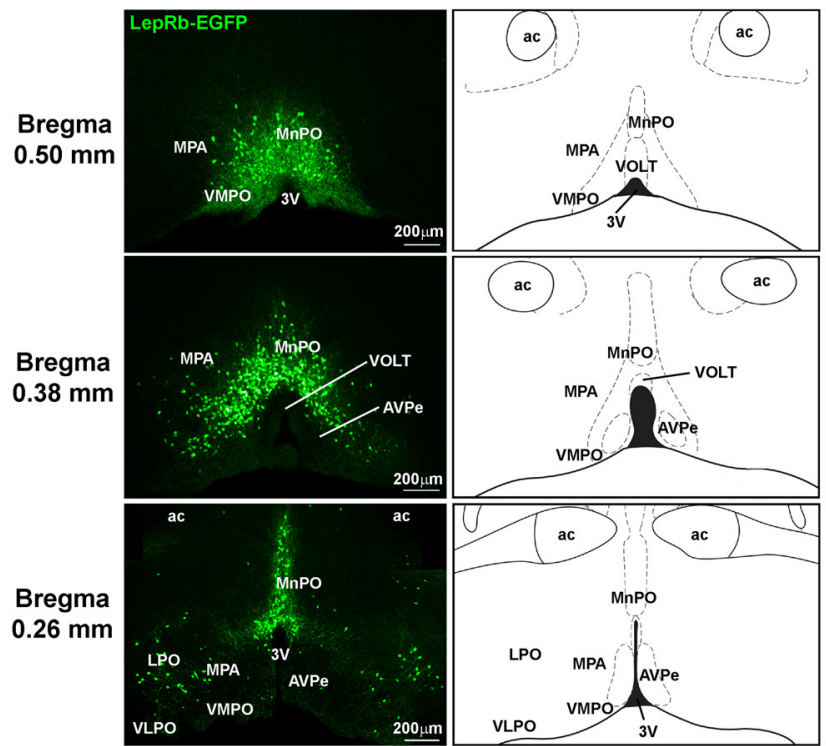

D

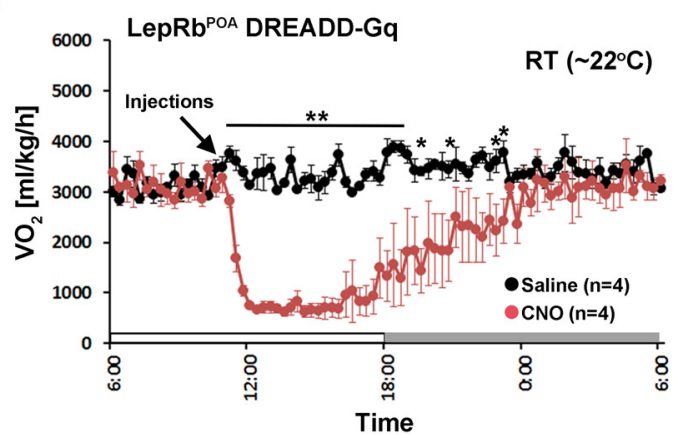

B

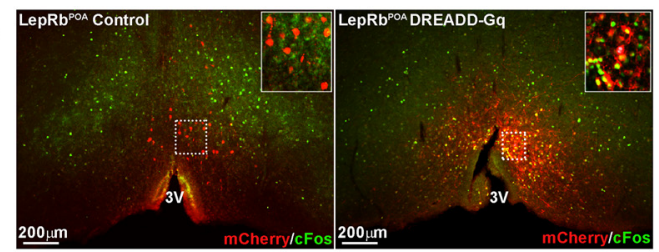

C

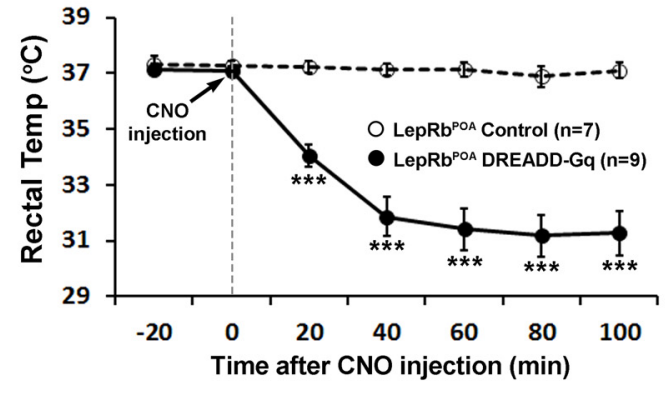

E

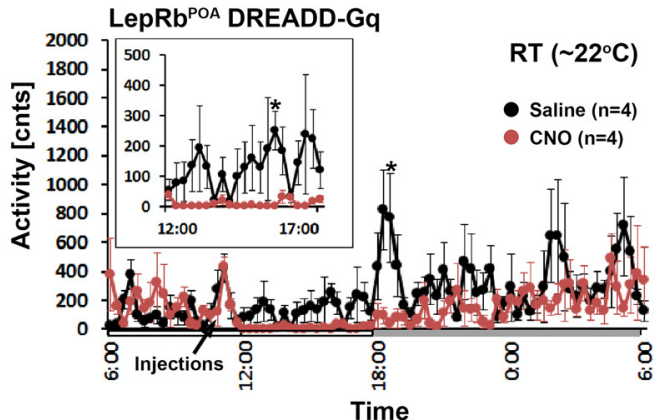

F

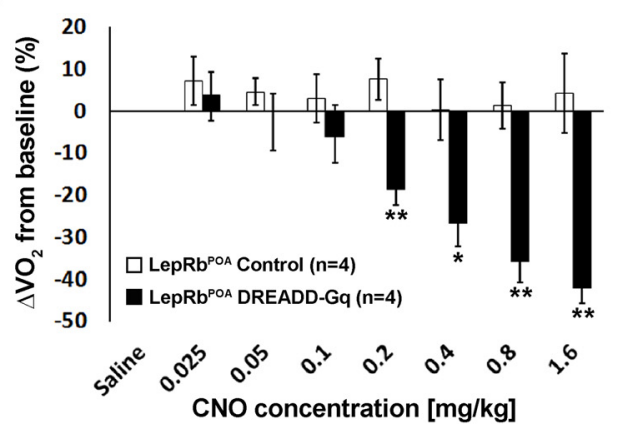

G

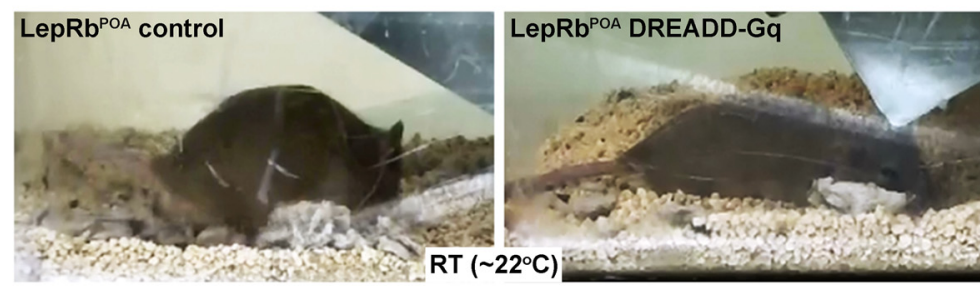

70 min after CNO injection

Figure 1. LepRb ${ }^{\mathrm{POA}}$ neurons decrease core temperature and energy expenditure. $\boldsymbol{A}$, Distribution of LepRb-expressing neurons in the POA of LepRb ${ }^{E G F P}$ reporter mice. Right panels show corresponding regions in the mouse brain atlas (Paxinos and Franklin, 2004). 3V, Third ventricle; MPA, medial preoptic area; LPO, lateral preoptic area; VOLT, vascular organ of the lamina terminalis; AVPe, anteroventral periventricular nucleus; VMPO, ventromedial preoptic nucleus; $\mathrm{VL} P \mathrm{P}$, ventrolateral preoptic nucleus; $\mathrm{MnPO}$, median preoptic nucleus; ac, anterior commissure. $\boldsymbol{B}$, Representative images showing virus-infected neurons (mCherry, red) and $\mathrm{CFos}$ (green) in the POA in LepR ${ }^{P O A}$ control and LepRb ${ }^{P O A}$ DREADD-Gq mice. CNO (0.5 mg/kg, i.p.) was injected 2-3 $\mathrm{h}$ before perfusion. Insets show magnified images of the indicated areas (dotted line boxes). C, Rectal temperature of LepRb ${ }^{P O A}$ control $(n=7)$ and LepRPBOA DREADD-Gq $(n=9) \mathrm{mice}$ after CNO injection (1.5 mg/kg, i.p.) at RT. $\boldsymbol{D}, V_{0}$ measurement in LepRb ${ }^{P O A}$ DREADD-Gq mice $(n=4)$ during saline (black) or CNO $\left(0.5 \mathrm{mg} / \mathrm{kg}\right.$, i.p.; red) injections at RT. E, Locomotor activity in the same LepRb $b^{P O A}$ DREADD-Gq mice shown in $\boldsymbol{D}$ during the same period. Locomotor activity from 12:00 to 6:00 P.M. is enlarged in the box. $\boldsymbol{F}$, Change in V0, (percentage) in LepRb $b^{P O A}$ control $(n=4)$ and LepRb ${ }^{P O A}$ DREADD-Gq $(n=4)$ mice at different CNO concentrations at RT. G, Photos capturing postural extension $70 \mathrm{~min}$ after CNO injection ( $1.5 \mathrm{mg} / \mathrm{kg}$, i.p.) in a LepRb ${ }^{\text {POA }}$ DREADD-Gq mouse compared with a control mouse at $\mathrm{RT}$ in their home cages. Data are represented as mean $\pm \mathrm{SEM}^{*} p<0.05,{ }^{* *} p<0.01$, and ${ }^{* * *} p<0.0001$ (two-way repeated-measures ANOVA and Bonferroni's pairwise comparisons).

DREADD-Gq $(n=4)$ mice were trained to consume their daily food within 4 h during the light phase (CT3-CT7). After $3 \mathrm{~d}$, mice reached steady-state body weight ( $-13 \sim 14 \%$ compared with initial body weight) and were injected with saline or $\mathrm{CNO}(0.2 \mathrm{mg} / \mathrm{kg}$, i.p. $)$ on alternating days, $30 \mathrm{~min}$ before the feeding session. Food intake was recorded and compared between groups and treatments for the initial $2 \mathrm{~h}$ (CT3-CT5). Food was removed at CT7 and mice were moved to new cages. Average $2 \mathrm{~h}$ food intake was calculated from day 3 and 5 for saline and from day 4 and 6 for CNO injections (see Fig. 4C).
cFos induction in LepRb ${ }^{E G F P}$ mice at different ambient temperatures. Four-month-old male $L e p R b^{E G F P}$ mice were single-housed and acclimated to environmental chambers at RT over $4 \mathrm{~d}$, and they were exposed to either $4^{\circ} \mathrm{C}(n=6), 30^{\circ} \mathrm{C}(n=6)$, or maintained at RT $(n=9)$ for $3 \mathrm{~h}$. Mice were perfused and brains were further processed for immunohistochemical analysis of cFos induction in LepRb ${ }^{\text {POA }}$ EGFP neurons.

Leptin-induced phosphorylation of signal transducer and activator of transcription 3 in Vglut $2^{\text {EYFP }}$ and Vgat ${ }^{\text {EFP }}$ mice. Functional LepRb neurons were visualized by immunohistological detection of leptin-induced 
A

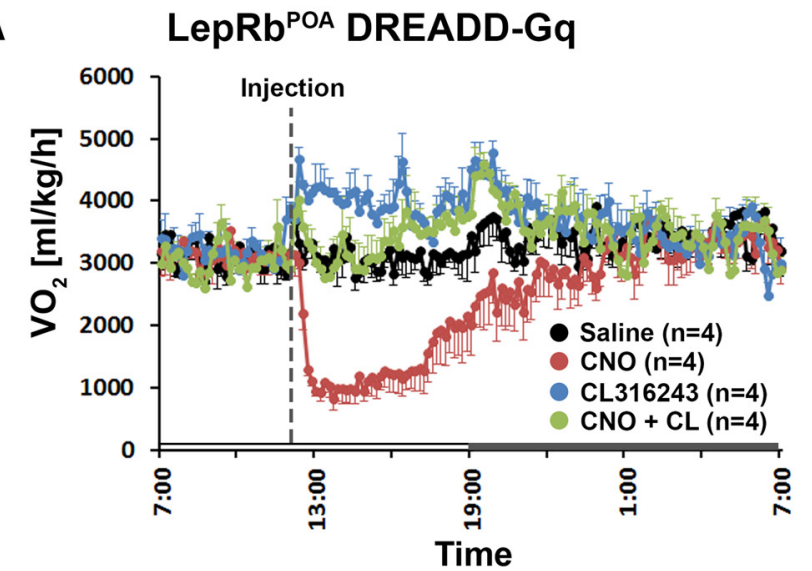

B

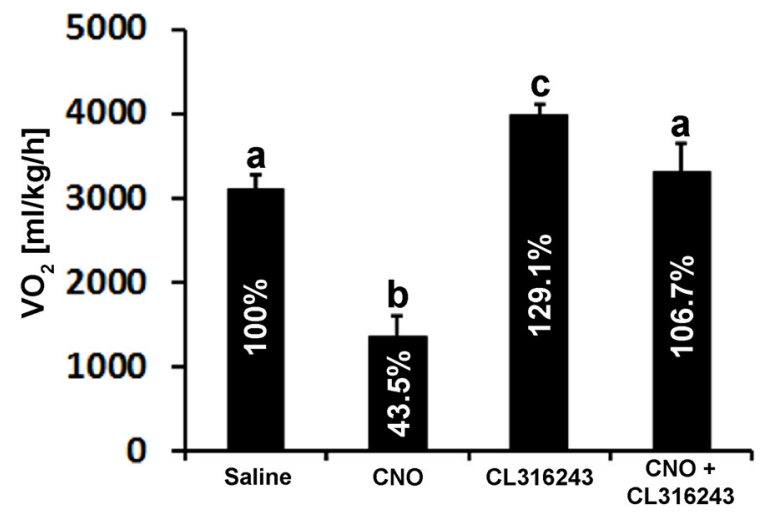

C

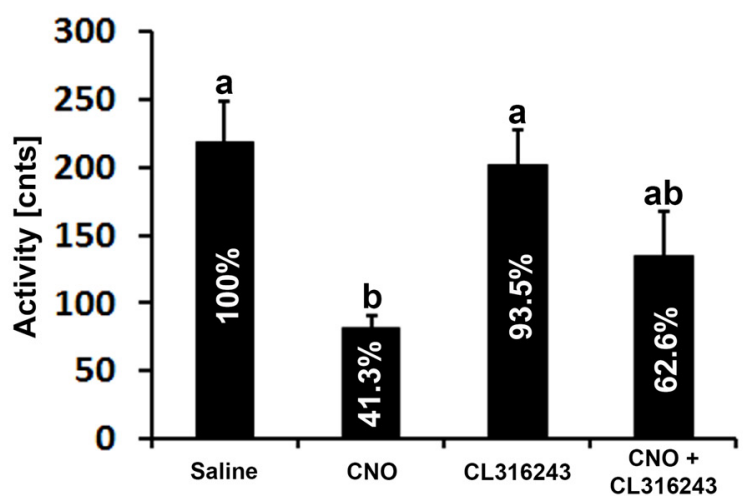

Figure 2. LepRb ${ }^{\mathrm{POA}}$ neurons inhibit $\beta 3$ adrenergic receptor-dependent $\mathrm{BAT}$ thermogenesis. $A, 24 \mathrm{~h} \mathrm{VO}_{2}$ measurement in LepRb ${ }^{P O A}$ DREADD-Gq mice $(n=4)$ after injections of saline (black), CNO (0.5 mg/kg, i.p.; red), CL316,243 (1.0 mg/kg, i.p.; blue), or CNO + CL316,243 (green). $\boldsymbol{B}$, The average $\mathrm{VO}_{2}$ during $6 \mathrm{~h}$ of postinjection was compared between injections. Values inside columns represent percentages compared with the saline injection. $C$, The average locomotor activity during $6 \mathrm{~h}$ after injection was compared between injections. Values inside columns represent percentages compared with the saline injection. Data are represented as mean \pm SEM. Bars with different letters denote significant differences at $p<0.05$ (one-way repeatedmeasures ANOVA and Fisher's least significant difference pairwise comparisons).

phosphorylation of signal transducer and activator of transcription 3 (pSTAT3; Faouzi et al., 2007; Laque et al., 2015). To identify whether LepRb ${ }^{\mathrm{POA}}$ neurons are excitatory glutamatergic or inhibitory GABAergic, male $\operatorname{Vglut} 2^{E Y F P}$ and $\operatorname{Vgat} t^{E Y F P}$ mice $(n=3$ each) received a bolus injection of murine leptin $(5 \mathrm{mg} / \mathrm{kg}$, i.p.; National Hormone and Peptide Program, http://www.humc.edu/hormones) and were perfused $1 \mathrm{~h}$ later. Brains were further processed for immunohistochemical detection of pSTAT3 and enhanced yellow fluorescent protein (EYFP).

Perfusion and immunohistochemistry. Perfusions and immunohistochemistry were performed as previously described (Zhang et al., 2011).
Briefly, deeply anesthetized mice were transcardially perfused with ice-cold physiological saline, followed by $10 \%$ formalin. Brains were removed and postfixed in $10 \%$ formalin overnight at $4^{\circ} \mathrm{C}$ and cryoprotected in $30 \%$ sucrose. Brains were sliced at $30 \mu \mathrm{m}$ thickness and processed for free-floating immunohistochemistry. pSTAT3 and occasionally cFos were visualized by diaminobenzene (DAB; \#34065, Thermo Fisher Scientific) following treatment with Vectastain ABC (\#PK-6100, Vector Laboratories) after incubation with biotinylated secondary antibodies. All other proteins were visualized by fluorophore-labeled secondary antibodies. Primary antibodies used are goat anti-cFos (1:200; \#sc-52-G, Santa Cruz Biotechnology), rabbit anti-cFos (1:3000; \#PC38, EMD Millipore), rabbit anti-pSTAT3 (Tyr705; 1:500; \#9131, Cell Signaling Technology), rabbit anti-dsRed (1:500; \#632496, Clontech Laboratories), and chicken anti-GFP (1:1000; \#ab13970, Abcam). Secondary antibodies used were donkey anti-goat IgG-Alexa594 (\#A11058, Life Technologies), donkey anti-goat IgG-Alexa488 (\#A11055, Life Technologies), donkey anti-rabbit IgG-Alexa594 (\#A21207, Life Technologies), donkey anti-chicken IgY-DyLight488 (\#703-486-155, Jackson ImmunoResearch Laboratories), donkey anti-goat IgG-biotin (\#705-065-003, Jackson ImmunoResearch Laboratories), and donkey anti-rabbit IgG-biotin (\#711-065152, Jackson ImmunoResearch Laboratories).

Microscopy and estimates of cell counts. Immunohistochemistry staining was visualized with a fluorescent microscope (\#BX51, Olympus), and images were taken with a digital camera (\#DP30BW, Olympus) using appropriate filters for different fluorophores or bright-field illumination for DAB stains. Images from identical areas were taken for double immunohistochemistry, overlaid, and pseudocolored using Adobe Photoshop CS6 (Adobe Systems). Contrast and brightness were adjusted with identical settings for all images within an experiment using Adobe Photoshop CS6 for better visualization of signals.

To determine the percentage of LepR $\mathrm{R}^{\mathrm{POA}}$ neurons that were activated by different temperature exposures, total $\mathrm{LepRb}^{\mathrm{POA}}-\mathrm{EGFP}^{+}$neurons and LepRb ${ }^{\mathrm{POA}}-\mathrm{EGFP} / \mathrm{cF}$ os double-positive cells were counted to calculate the percentage of $\mathrm{cFos}^{+} \mathrm{LepRb}^{\mathrm{POA}}$ neurons. The anatomical extent of the POA area subjected for cell counts was defined by the expression of LepRb$\mathrm{EGFP}^{+}$neurons, which are found within 2-3 sections (from bregma +0.62 to $+0.26 \mathrm{~mm}$ along the rostrocaudal axis) using one of four series of $30-\mu \mathrm{m}$-thick coronal sections per animal. Thus, the total number of LepRb ${ }^{\mathrm{POA}}$-EGFP ${ }^{+}$neurons was estimated by cell counts and the coexpression with cFos was assessed within these identified LepRb ${ }^{\text {POA }}$-EGFP ${ }^{+}$ neurons. Cell counts were done manually and positive cells were identified individually by an investigator for the appearance of cytoplasmic $\left(\mathrm{EGFP}^{+}\right)$or nuclear (cFos) fluorescent stain. Any stain that could not be easily identified as a cytoplasmic or nuclear stain was omitted from cell counts.

To quantify leptin-induced pSTAT3 in Vglut2 $2^{\text {EYFP }}$ and Vgat ${ }^{\text {EYFP }}$ mice, total numbers of pSTAT3 $^{+}$neurons in the POA and pSTAT3/EYFP doublepositive cells were counted to calculate the percentage of glutamatergic or GABAergic LepRb ${ }^{\mathrm{POA}}$ neurons ( $n=3$ for each group). Similar to the method mentioned above, we defined the POA area by the appearance of LepRb neurons. Here LepRb neurons were identified by the expression of leptin-induced pSTAT3 (DAB stain) as a surrogate for LepRb neurons. Again we consistently identified 2-3 sections per animal for cell counts and the total number of $\mathrm{PSTAT}^{+}{ }^{+}$neurons was estimated by cell counts and the coexpression with $\mathrm{EGFP}^{+}$vesicular GABA transporter (Vgat) or vesicular glutamate transporter 2 (Vglut2) neurons was further assessed within these identified $\mathrm{pSTAT}^{+}{ }^{+}$neurons. Cell counts were done manually by an investigator as noted above.

Statistical analysis. All data were statistically analyzed by SPSS 22 (IBM). See results and figure legends for individual statistical test. $p<0.05$ was considered statistically significant in all experiments.

\section{Results}

Pharmacogenetic activation of LepRb ${ }^{\text {POA }}$ neurons decreases core temperature and energy expenditure

LepRb in the POA is mainly expressed in the median preoptic nucleus (MnPO; Fig. 1A). Because LepRb ${ }^{\text {POA }}$ neurons are connected to sympathetic premotor neurons and multisynaptically 
project to BAT (Zhang et al., 2011), we hypothesized that LepRb ${ }^{\text {POA }}$ neurons would likely modulate energy expenditure by controlling BAT activity.

To test this idea, DREADD-Gq was selectively expressed in LepRb ${ }^{\mathrm{POA}}$ neurons of $L e p R b^{\text {Cre }}$ mice (LepR $b^{P O A}$ DREADD-Gq). Subsequent CNO injection strongly induced cFos (a neuronal activation marker) in virus-infected cells (indicated by mCherry $^{+}$neurons) in LepR $b^{P O A}$ DREADD-Gq mice, but not in mice injected with control virus (Fig. $1 B$ ). CNO injection induced a robust drop of rectal temperature that reached the nadir $\sim 1 \mathrm{~h}$ after the CNO injection in $L e p R b^{P O A}$ DREADD-Gq, but not in control mice (Fig. $1 C$; repeated-measures ANOVA for the interaction between time and group: $F_{(6,84)}=$ $34.99, p<0.001)$. Only mice with correct DREADD-Gq expression in LepRb ${ }^{\text {POA }}$ neurons decreased rectal temperature with $\mathrm{CNO}$ (data not shown).

Consistent with the reduced core temperature phenotype, CNO-induced activation of LepRb ${ }^{\mathrm{POA}}$ neurons significantly decreased energy expenditure $\left(\mathrm{VO}_{2}\right)$ by $80 \% \quad$ (Fig. 1D; repeated-measures ANOVA for the effect of treatment during $6 \mathrm{~h}$ postinjection: $F_{(1,3)}=189.55, p<$ $0.01)$. During the same period, locomotor activity and RER also significantly decreased (Fig. 1E; repeated-measures ANOVA for the effect of treatment during $6 \mathrm{~h}$ postinjection: $F_{(1,3)}=15.06, p<0.05$; data not shown), indicating that part of the reduction in energy expenditure was due to decreased activity. The degree and duration of $\mathrm{VO}_{2}$ decrease was $\mathrm{CNO}$ dose dependent (Fig. 1F; repeated-measures ANOVA for the interaction between concentration and group: $F_{(7,42)}=7.85, p<$ 0.001 ), while locomotor activity and RER only showed trends of CNO dose dependency (data not shown), suggesting direct $\mathrm{CNO}$ effects on $\mathrm{VO}_{2}$, while locomotor activity and RER may passively follow the direct changes in $\mathrm{VO}_{2}$. Activation of LepRb ${ }^{\text {POA }}$ neurons also promoted a postural extension (Fig. $1 G$ ), a typical behavioral response in mice exposed to higher ambient temperature (Roberts, 1988). LepR $b^{P O A}$ DREADD-Gq mice with CNO injection were mostly immobile but awake and alert (Fig. 1E; data not shown).

LepRb ${ }^{\text {POA }}$ neurons inhibit $\beta 3$ adrenergic receptor-dependent BAT thermogenesis

Next, we aimed to verify that LepRb ${ }^{\text {POA }}$ neurons act via sympathetic outputs to BAT. The $\beta 3 \mathrm{AR}$ is predominantly expressed in BAT and white adipose tissue, and mediates adaptive thermogenesis by promoting expression of uncoupling protein 1 and lipolysis (Susulic et al., 1995; Grujic et al., 1997; Collins et al., 2010).
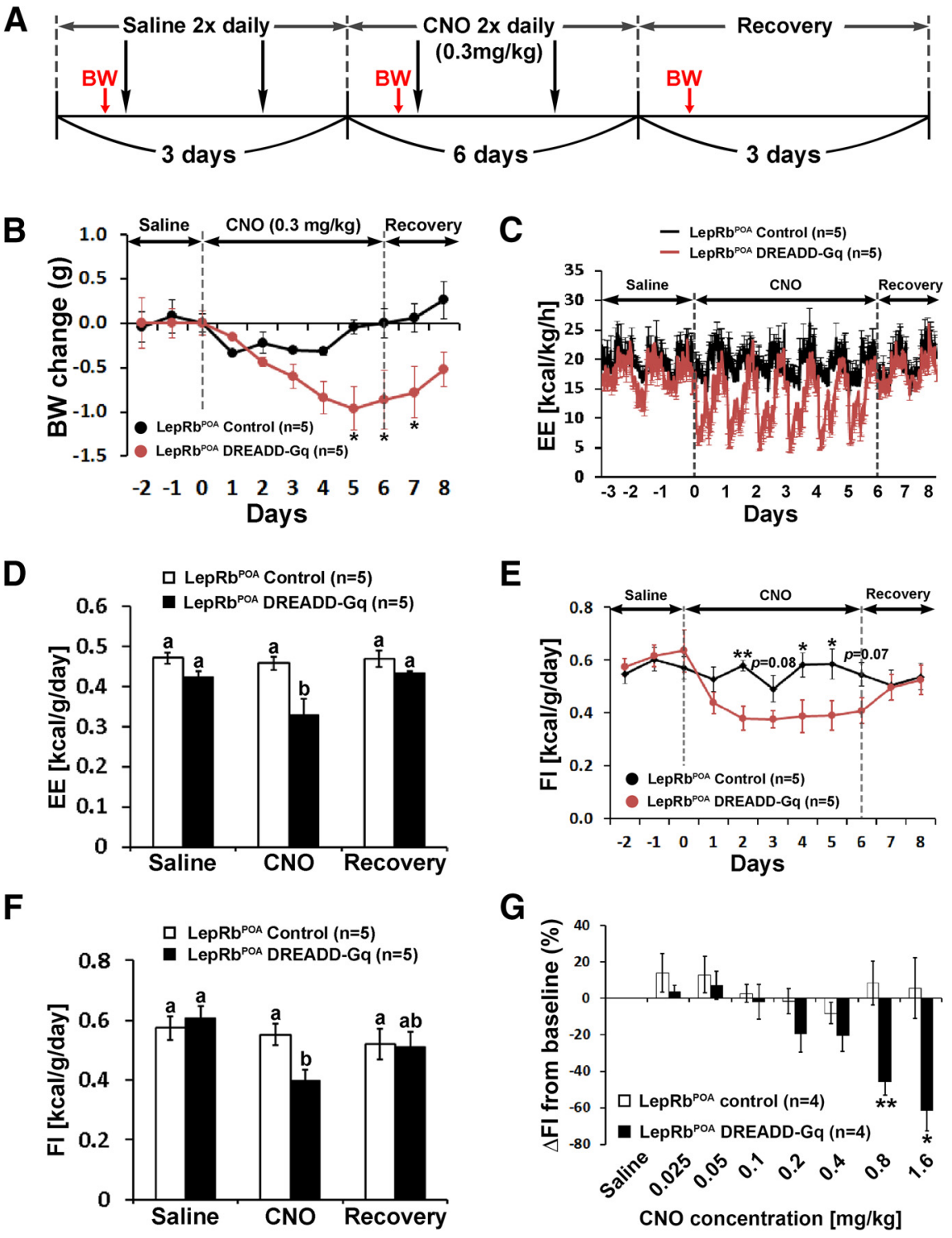

Figure 3. Chronic activation of LepRb ${ }^{\mathrm{POA}}$ neurons. $\boldsymbol{A}$, The experimental scheme showing timings of body weight measurement and injections for chronic CNO treatment. CNO was injected intraperitoneally twice daily at $0.3 \mathrm{mg} / \mathrm{kg}$ for 6 consecutive days following $3 \mathrm{~d}$ of saline injections, and no injection was made during $3 \mathrm{~d}$ of recovery. $\boldsymbol{B}$, Body weight of $L e p R b^{P O A} \operatorname{control}(n=5)$ and LepR $b^{P O A}$ DREADD-Gq $(n=5)$ mice during chronic CNO treatment. C, CNO reduced energy expenditure during $6 \mathrm{~d}$ of CNO treatment in LepRb ${ }^{P O A}$ DREADD-Gq $(n=5)$ but not in control $(n=5)$ mice. $D$, Average daily energy expenditure $(\mathrm{kcal} / \mathrm{g} / \mathrm{d})$ was compared between groups and treatments. $\boldsymbol{E}$, Chronic CNO reduced daily food intake in LepRb ${ }^{P O A}$ DREADD-Gq $(n=5)$ but not in control ( $n=$ 5) mice. $\boldsymbol{F}$, Average daily food intake ( $\mathrm{kcal} / \mathrm{g} / \mathrm{d}$ ) was compared between groups and treatments. $\boldsymbol{G}$, Change in food intake (percentage) in LepRb ${ }^{P O A}$ control $(n=4)$ and LepRb ${ }^{P O A}$ DREADD-Gq $(n=4)$ mice at different CNO concentrations at RT. Data are represented as mean $\pm \mathrm{SEM}{ }^{*} p<0.05,{ }^{* *} p<0.01$, and bars with different letters denote significant differences at $p<0.05$ (two-way repeated-measures ANOVA and Bonferroni's pairwise comparisons).

As expected, a systemic injection of CL316,243, a $\beta 3$ AR agonist, increased $\mathrm{VO}_{2}$ (Fig. $2 A, B$; repeated-measures ANOVA for the effect of treatment for $6 \mathrm{~h}$ mean of postinjection in $B: F_{(3,9)}=121.89, p<$ $0.001)$ in $L e p R b^{P O A}$ DREADD-Gq mice without affecting locomotor activity (Fig. 2C; repeated-measures ANOVA for the effect of treatment for $6 \mathrm{~h}$ mean of postinjection: $\left.F_{(3,9)}=8.77, p<0.01\right)$. The combined injection of CL316,243 with CNO prevented the CNOmediated $\mathrm{VO}_{2}$ decrease (Fig. $2 \mathrm{~A}, B$ ), which is consistent with a model hypothesizing that activation of LepRb ${ }^{\text {POA }}$ neurons suppresses $\beta 3 \mathrm{AR}$-induced adaptive thermogenesis.

The coinjection of CL316,243 and CNO modestly recovered CNO-decreased locomotor activity even though CL316,243 
A

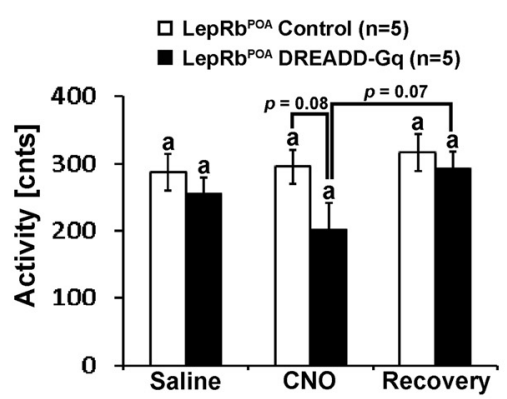

B

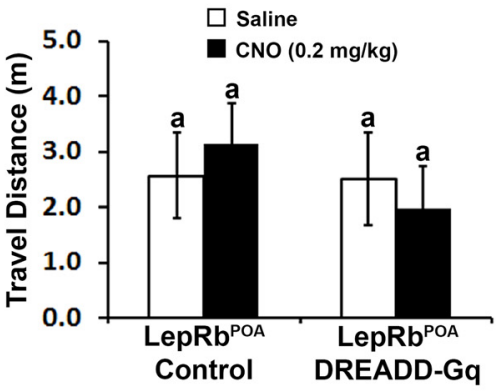

C

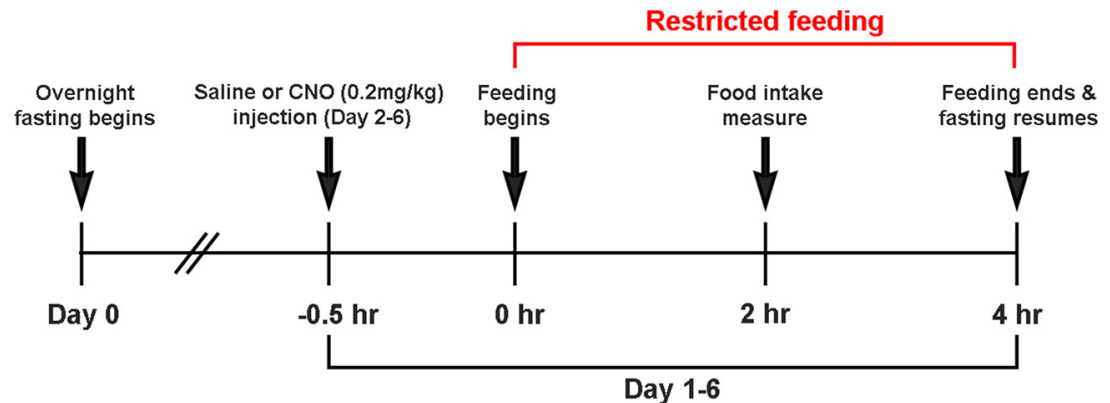

D

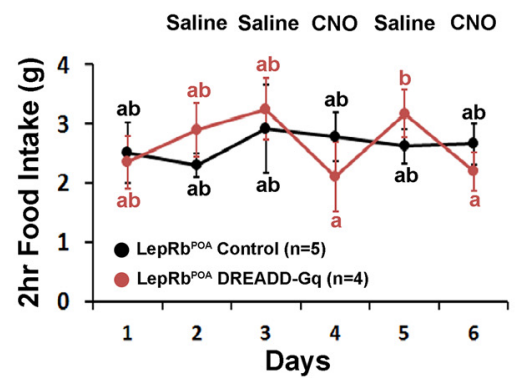

$E$

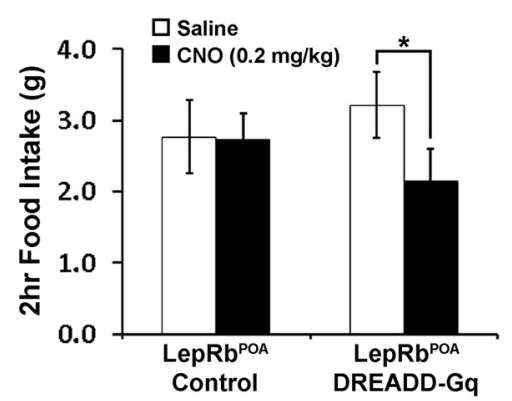

Figure 4. LepRb $b^{\mathrm{POA}}$ neurons modulate food intake. $\boldsymbol{A}$, Average daily locomotor activity was compared between groups and treatments during chronic CNO treatment. $\boldsymbol{B}$, Total travel distance during 5 min was compared between groups (control, $n=5$; DREADD-Gq, $n=4$ ) and treatments 30 min after injections. C, The experimental scheme for restricted feeding. $D$, The first $2 \mathrm{~h}$ food intake during restricted feeding was measured in $L e p R b^{P O A}$ control $(n=5)$ and $L e p R b^{P O A}$ DREADD-Gq $(n=4)$ mice. Only LepRb $b^{P O A}$ DREADD-Gq mice reduced food intake by CNO injection. $\boldsymbol{E}$, Average $2 \mathrm{~h}$ food intake during the restricted feeding (control, $n=5$; DREADD-Gq, $n=4)$. Saline data are from days 3 and 5 , and CNO data are from days 4 and 6 . Data are represented as mean \pm SEM. ${ }^{*} p<0.01$ (paired $t$ test). Data with different letters denote significant differences at $p<0.05$ (two-way repeated-measures ANOVA and Bonferroni's pairwise comparisons).

alone did not affect locomotor activity (Fig. 2C). Thus, the increased locomotor activity from the coinjection may not be a direct consequence of the activation of the $\beta 3 \mathrm{AR}$, but rather a secondary effect of elevated core temperature.

LepRb ${ }^{\mathrm{POA}}$ neurons modulate food intake and body weight We further tested how the dramatic decrease in energy expenditure would influence body weight during chronic activation of LepRb ${ }^{\text {POA }}$ neurons. A group of $L e p R b^{P O A}$ control and $L e p R b^{P O A}$ DREADD-Gq mice were injected with low-dose CNO (0.3 mg/ $\mathrm{kg}$, i.p.) twice daily for $6 \mathrm{~d}$. Body weight, food intake, energy expenditure, and locomotor activity were monitored (Fig. $3 A$ ).

Chronic activation of LepRb ${ }^{\mathrm{POA}}$ was expected to cause a positive energy balance and body weight gain. Unexpectedly, body weight of $L e p R b^{P O A}$ DREADD-Gq mice gradually decreased during daily $\mathrm{CNO}$ treatment and started to return to preinjection levels once the CNO injection stopped (Fig. 3B; repeatedmeasures ANOVA for the interaction between day and group: $\left.F_{(10,80)}=3.07, p<0.01\right)$. Twenty-four hour energy expenditure decreased during daily $\mathrm{CNO}$ injections as expected (Fig. 3C,D; repeated-measures ANOVA for the interaction between treatment and group in $D$ : $\left.F_{(2,16)}=4.61, p<0.05\right)$, implying a simultaneous reduction of food intake. Indeed, daily food intake decreased significantly during $\mathrm{CNO}$ injections and recovered to normal levels without any signs of compensatory overfeeding after $\mathrm{CNO}$ injections stopped (Fig. 3E,F; repeatedmeasures ANOVA for the interaction between day and group in $E: F_{(10,80)}=$ 3.01, $p<0.01$; between treatment and group in $\left.F: F_{(2,16)}=3.93, p<0.05\right)$. We also found that food intake decreased CNO dose-dependently (Fig. 3G; repeated-measures ANOVA for the interaction between concentration and group: $\left.F_{(7,42)}=6.62, p<0.001\right)$, similar to the decrease in energy expenditure (Fig. $1 F$ ).

Although we used a relatively low $\mathrm{CNO}$ dose for the daily treatment, we worried that the effects of low core temperature on locomotor activity may have physically limited normal feeding behavior even though locomotor activity of $L e p R b^{P O A}$ DREADD-Gq mice did not significantly decrease during $\mathrm{CNO}$ treatment (Fig. 4A; repeated-measures ANOVA for the interaction between treatment and group: $F_{(2,16)}=1.91, p>$ $0.05)$. In a new cohort of $L e p R b^{P O A}$ DREADD-Gq mice, we found that a CNO dose of $0.2 \mathrm{mg} / \mathrm{kg}$ did not affect locomotor activity (Fig. 4B; repeated-measures ANOVA for the effect of treatment: $F_{(1,7)}$ $=0.002, p>0.05)$. Furthermore, we trained this cohort of control and $L e p R b^{P O A}$ DREADD-Gq mice to consume their daily food in a restricted $4 \mathrm{~h}$ time window, during which the mice would be maximally motivated to consume food. Saline or CNO was injected $30 \mathrm{~min}$ before the feeding session and the initial $2 \mathrm{~h}$ food intake was evaluated (Fig. 4C). CNO still reduced $2 \mathrm{~h}$ food intake in $L e p R b^{P O A}$ DREADD-Gq mice (Fig. $4 D$; repeated-measures ANOVA for the interaction between day and group: $F_{(5,35)}=$ $2.89, p<0.05)$. The comparison of average $2 \mathrm{~h}$ food intake between saline (days 3 and 5) and $\mathrm{CNO}$ (days 4 and 6) injections also showed significant difference $(-33 \%$ compared with saline treatment) only in $L e p R b^{P O A}$ DREADD-Gq mice (Fig. $4 E$; paired $t$ test for DREADD-Gq: $\left.t_{(3)}=8.00, p<0.01\right)$. Thus, these data overall further corroborate the finding that LepRb ${ }^{\mathrm{POA}}$ neurons indeed modulate food intake.

LepRb ${ }^{\text {POA }}$ neurons are activated by warm, but not by cold exposure

It has been suggested that POA neurons are inhibited by cold exposure, which leads to activation of BAT adaptive thermogenesis. Conversely, the adaptation to thermoneutral, warm ambient temperature causes a reduction in energy expenditure and inhibition of BAT adaptive thermogenesis (Cannon and Nedergaard, 2011). Thus, we hypothesized that LepRb ${ }^{\text {POA }}$ neurons may be similarly affected by ambient temperature. We initially 
A

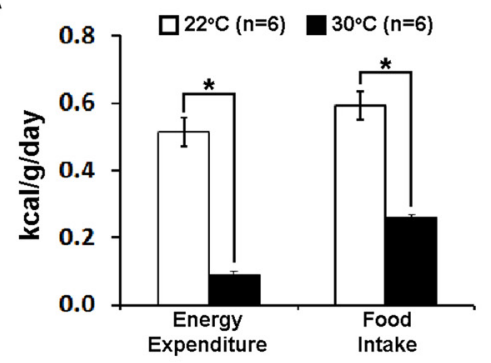

B

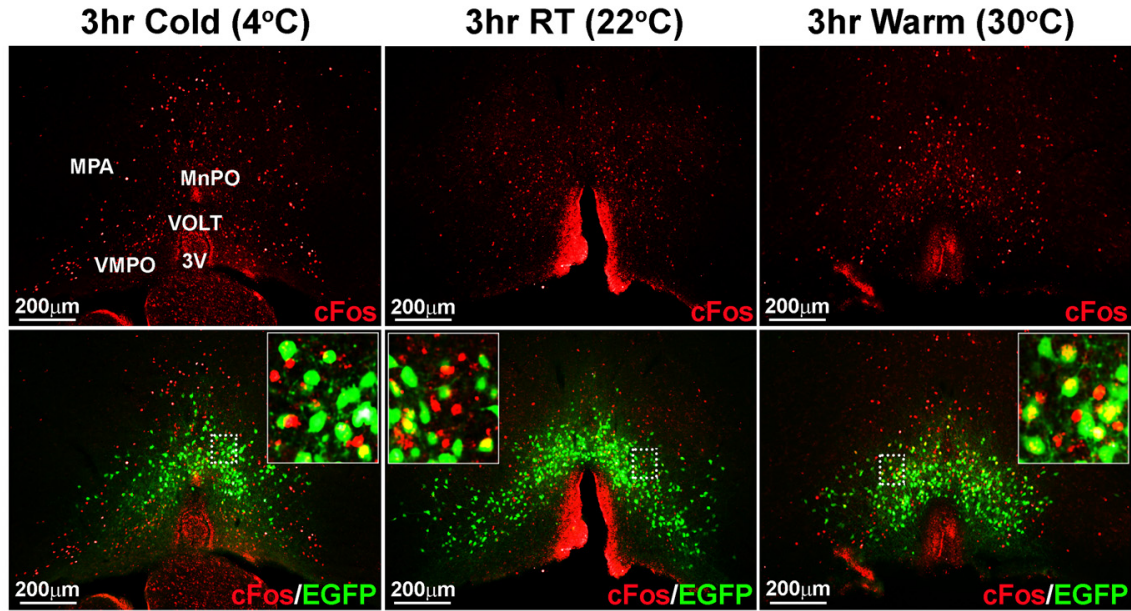

C

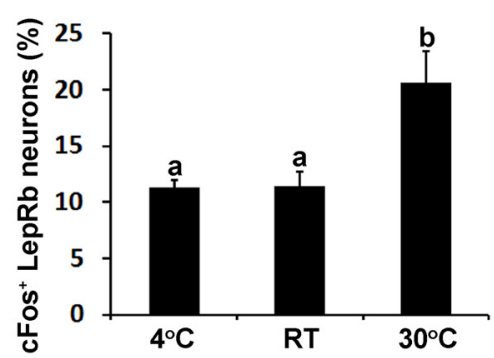

D

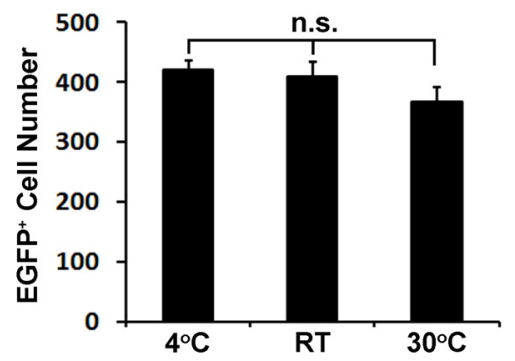

E

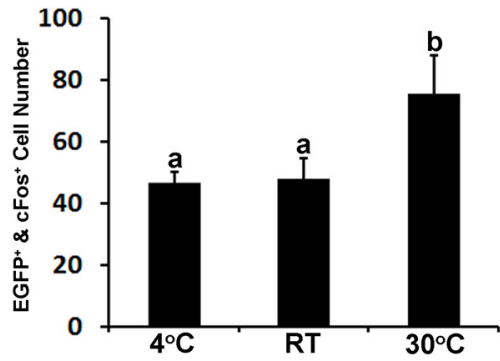

Figure 5. LepRb ${ }^{P 0 A}$ neurons are activated by warm exposure, but not by cold exposure. $A$, Comparisons of energy expenditure and food intake between mice housed at $22^{\circ} \mathrm{C}(n=6)$ and $30^{\circ} \mathrm{C}$ $(n=6) . B$, Representative immunohistochemical images showing the distribution of $c$ Fos (red, top panels) and $c$ Fos $/$ LepRb ${ }^{\text {POA }}-\mathrm{EGFP}$ (bottom panels) after 3 h of cold $\left(4^{\circ} \mathrm{C} ; n=6\right), \mathrm{RT}\left(22^{\circ} \mathrm{C} ; n=\right.$ 9), and warm $\left(30^{\circ} \mathrm{C} ; n=6\right.$ ) exposure in LepRb ${ }^{\text {EGFP }}$ mice. Insets show magnified images of the indicated areas (dotted line boxes). $\boldsymbol{C}$, The percentage of LepRb ${ }^{\text {POA }}$-EGFP cells that express CFos was calculated for each temperature condition. $\boldsymbol{D}, \boldsymbol{E}$, Total number of EGFP ${ }^{+}(\boldsymbol{D})$ and EGFP ${ }^{+} / \mathrm{CFOS}^{+}(\boldsymbol{E})$ cells in the POA counted in each temperature condition. ${ }^{*} p<0.001$ (independent $t$ test). Data with different letters denote significant differences at $p<0.01$ for $\boldsymbol{C}$ and $p<0.05$ for $\boldsymbol{E}$ (one-way ANOVA and Fisher's least significant difference pairwise comparisons). n.s., Not significant.

tested whether the physiological adaptation to warm temperature $\left(30^{\circ} \mathrm{C}\right)$ results in similar changes of energy expenditure and food intake as observed after pharmacogenetic activation of LepRb ${ }^{\text {POA }}$ neurons. Indeed, energy expenditure and food intake dramatically decreased at $30^{\circ} \mathrm{C}$ compared with RT (Fig. $5 \mathrm{~A}$; independent $t$ test: for energy expenditure, $t_{(10)}=15.32, p<0.001$; for food intake, $t_{(10)}=7.72, p<0.001$ ), thus reflecting the same physiological changes as observed by pharmacogenetic activation of LepRb ${ }^{\text {POA }}$ neurons.

We next tested how changes in ambient temperature affect activity of LepRb ${ }^{\mathrm{POA}}$ neurons. LepR $b^{E G F P}$ mice were exposed to cold temperature $\left(4^{\circ} \mathrm{C}\right)$, RT $\left(22^{\circ} \mathrm{C}\right)$, or warm temperature $\left(30^{\circ} \mathrm{C}\right)$ for $3 \mathrm{~h}$, and $c$ Fos induction in LepRb ${ }^{\text {POA }}$-EGFP neurons was analyzed. Only warm exposure increased the number of $\mathrm{cFos}^{+}$ LepRb ${ }^{\text {POA }}$ neurons by approximately twofold (Fig. 5B, $C$; ANOVA in $\left.C: F_{(2,18)}=8.67, p<0.01\right)$. While the total number of LepRb ${ }^{\text {POA }}$-EGFP cells was similar in all groups (Fig. $5 D$; ANOVA: $\left.F_{(2,18)}=1.50, p>0.05\right)$, the number of LepRb ${ }^{\text {POA }}-$ EGFP and cFos double-positive cells was only increased at $30^{\circ} \mathrm{C}$ (Fig. $5 E$; ANOVA: $\left.F_{(2,18)}=3.82, p<0.05\right)$, suggesting that pharmacogenetic activation of LepRb ${ }^{\mathrm{POA}}$ neurons mimics the physiological response to warm temperature, except that their activation at RT resulted in hypothermia (Fig. 1C).

Based on these results, we predicted that the effect of pharmacogenetic LepRb ${ }^{\mathrm{POA}}$ neuronal activation should be minimal at thermoneutral temperature, because LepRb ${ }^{\mathrm{POA}}$ neurons are already activated and adaptive thermogenesis is minimal. Conversely, pharmacogenetic activation of LepRb ${ }^{\mathrm{POA}}$ neurons should have maximal effects at cold ambient temperature be- cause LepRb ${ }^{\mathrm{POA}}$ neurons should be naturally inhibited to promote adaptive thermogenesis.

To test this idea, we injected saline or CNO into $L e p R b^{P O A}$ DREADD-Gq mice $1 \mathrm{~h}$ after the temperature change from RT to cold $\left(10^{\circ} \mathrm{C}\right)$ or warm $\left(30^{\circ} \mathrm{C}\right.$; Fig. $\left.6 \mathrm{~A}\right)$. As predicted, at $30^{\circ} \mathrm{C}$, pharmacogenetic activation of LepRb ${ }^{\mathrm{POA}}$ neurons resulted in a minimal, albeit significant, decrease in $\mathrm{VO}_{2}$ (Fig. $6 \mathrm{~B}$; repeatedmeasures ANOVA for the effect of treatment during $6 \mathrm{~h}$ postinjection, $\left.F_{(1,3)}=129.51, p<0.01\right)$; conversely, at $10^{\circ} \mathrm{C}$, $\mathrm{CNO}$ injection vastly attenuated cold-induced $\mathrm{VO}_{2}$ increase (Fig. 6C; repeated-measures ANOVA for the effect of treatment during $6 \mathrm{~h}$ postinjection: $\left.F_{(1,3)}=38.45, p<0.01\right)$. The $\mathrm{VO}_{2}$ difference $\left(\Delta \mathrm{VO}_{2}\right)$ between saline and $\mathrm{CNO}$ injections at different temperatures was largest at $10^{\circ} \mathrm{C}$ and smallest at $30^{\circ} \mathrm{C}$ (Fig. $6 D, E$; repeated-measures ANOVA for the interaction between temperature and treatment in $D: F_{(2,6)}=39.69, p<$ 0.001 ; for the effect of temperature in $E: F_{(2,6)}=36.69, p<$ $0.001)$, thus confirming our initial prediction that the effect of pharmacogenetic LepRb ${ }^{\text {POA }}$ neuronal activation should be minimal at $30^{\circ} \mathrm{C}$ because LepRb ${ }^{\mathrm{POA}}$ neurons are already activated and adaptive thermogenesis is minimal. Locomotor activity and RER showed a similar trend as $\mathrm{VO}_{2}$ (Fig. 6F, G; repeated-measures ANOVA for the effect of treatment during $6 \mathrm{~h}$ postinjection in $F: F_{(1,3)}=4.85, p>0.05$; in $G: F_{(1,3)}=$ $66.27, p<0.01$; data not shown). Of note, the minimal $\mathrm{VO}_{2}$ level reached at $\mathrm{RT}$ was lower than that at $10^{\circ} \mathrm{C}$, implying that at $10^{\circ} \mathrm{C}$, other cold defense response (s), such as shivering, may have contributed to overall energy expenditure. Indeed, 
A

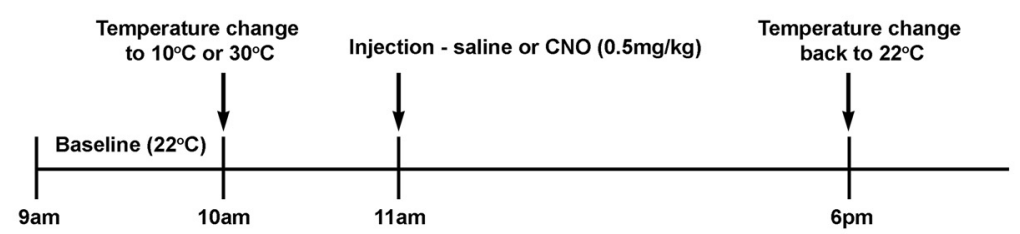

B

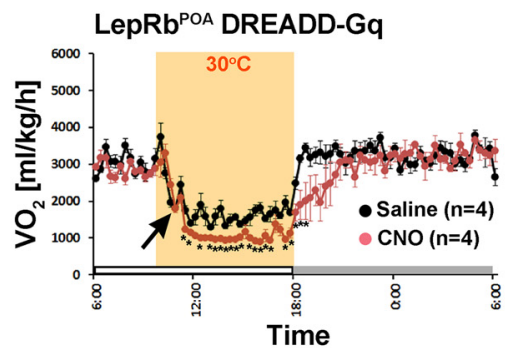

D

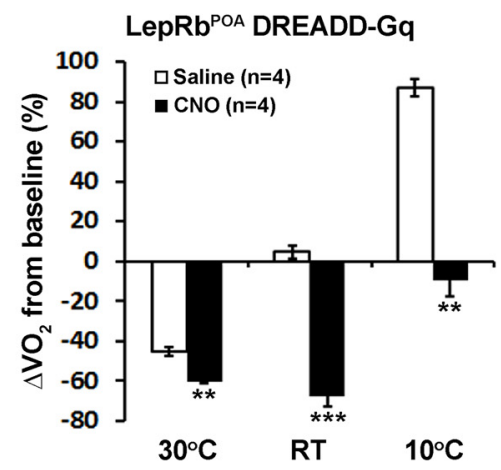

$\mathbf{F}$

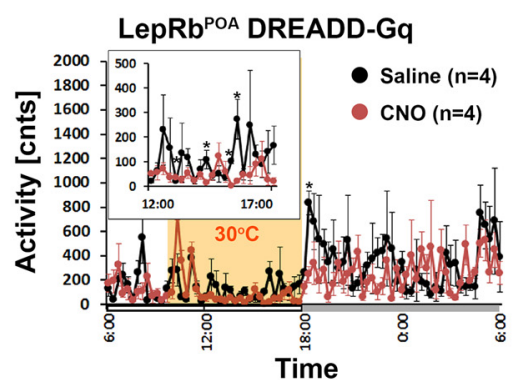

C

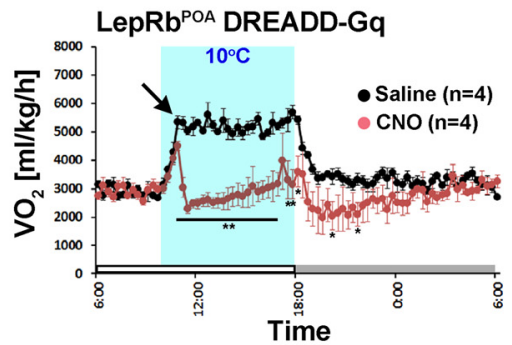

E

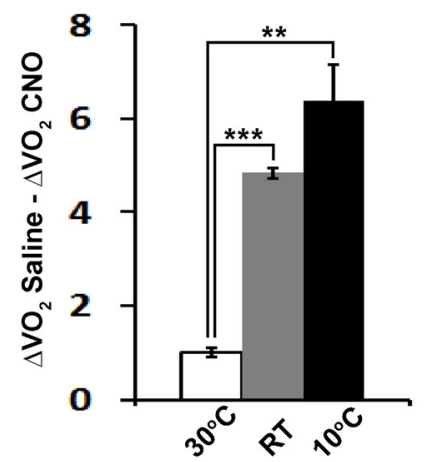

G

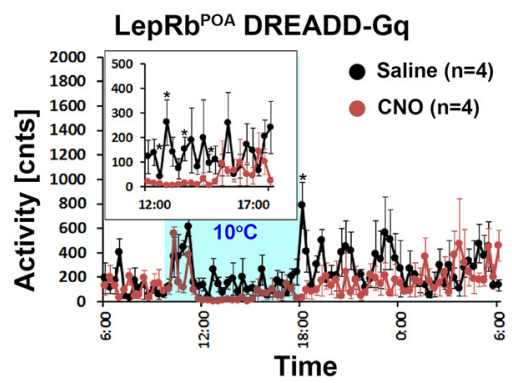

Figure 6. Pharmacogenetic activation of LepRb ${ }^{\mathrm{POA}}$ neurons at warm and cold ambient temperature. $\boldsymbol{A}$, The experimental scheme showing timings of temperature changes and injections for indirect calorimetry experiment. $B, A t 30^{\circ} \mathrm{C}$, LepRb ${ }^{P O A}$ DREADD-Gq mice further decreased $\mathrm{VO}_{2}$ by $\mathrm{CNO}$ injection compared with saline injection. $C$, At $10^{\circ} \mathrm{C}$, CNO injection greatly attenuated cold-induced increase in $\mathrm{VO}_{2}$ in LepRb ${ }^{P O A}$ DREADD-Gq mice. $D$, Average $\mathrm{VO}_{2}$ during $4 \mathrm{~h}$ postinjection was calculated and the change from baseline $\left(\Delta V \mathrm{O}_{2}\right)$ was compared between saline and $\mathrm{CNO}$ in each temperature condition. RT value is calculated from Figure $1 D$. $E, \Delta V \mathrm{O}_{2}$ Saline $-\Delta V \mathrm{O}_{2} \mathrm{CNO}$ was calculated for each temperature condition and normalized to $30^{\circ} \mathrm{C}$. $\boldsymbol{F}, \mathbf{G}$, Locomotor activity in the same LepRB ${ }^{P O A}$ DREADD-Gq mice shown in $\boldsymbol{B}$ and $\boldsymbol{C}$ during the same period. Locomotor activity from 12:00 to 6:00 P.M. is enlarged in the box. Data are represented as mean \pm SEM. ${ }^{*} p<0.05$, ${ }^{* *} p<0.01$, and ${ }^{* * *} p<0.001$ (two-way repeated-measures ANOVA and Bonferroni's pairwise comparisons for $\boldsymbol{B}-\boldsymbol{D}, \boldsymbol{F}$, and $\boldsymbol{G}$, and one-way repeated-measures ANOVA and Fisher's least significant difference pairwise comparisons for $\boldsymbol{E}$ ).

LepR $b^{P O A}$ DREADD-Gq mice injected with $\mathrm{CNO}$ at $10^{\circ} \mathrm{C}$ shivered noticeably (visual observation), revealing that LepRb ${ }^{\mathrm{POA}}$ neurons do not affect shivering thermogenesis.

Glutamatergic, not GABAergic, POA neurons mediate adaptations to ambient temperature

Previous studies suggested that GABAergic inhibitory inputs from the POA to the DMH and rostral medulla suppress BAT thermogenesis, and cold-induced inhibition of these signals pro- motes BAT thermogenesis (Nakamura, 2011). We hypothesized that LepRb ${ }^{\text {POA }}$ neurons represent those GABAergic POA neurons that inhibit BAT thermogenesis. Leptin-induced pSTAT3 is a reliable marker of LepRb-expressing neurons (Faouzi et al., 2007; Laque et al., 2015). Using reporter mice for Vglut2 $\left(\right.$ Vglut2 ${ }^{\text {EYFP }}$ mice) and Vgat (Vgat ${ }^{\text {EYFP }}$ mice) to visualize glutamatergic and GABAergic neurons, respectively (Vong et al., 2011; Xu et al., 2013), we analyzed their colocalization with leptin-induced pSTAT3 (Fig. 7).

Glutamatergic neurons are restricted to the $\mathrm{MnPO}$ and anteroventral periventricular nucleus, closely matching the expression pattern of LepRb in this area (Fig. $7 A-C$ ), while GABAergic neurons are more dispersed (Fig. 7D). We found that $58.42 \pm$ $6.49 \%$ of leptin-induced pSTAT3 ${ }^{+}$neurons were glutamatergic while only $18.93 \pm$ $2.64 \%$ were GABAergic ( $n=3$ each), and colocalized cells were mostly located in the ventrolateral regions of the MnPO (Fig. $7 E, F)$. This was surprising because of a discrepancy between our own data showing that LepRb ${ }^{\mathrm{POA}}$ neurons innervate the $\mathrm{DMH}$ and rostral medulla (Zhang et al., 2011) and literature that consistently suggests the GABAergic nature of warm-sensitive POA neurons that inhibit neurons in the DMH and rostral medulla (Nakamura, 2011).

To determine whether stimulation of glutamatergic versus GABAergic POA neurons reproduce the effect of pharmacogenetic activation of $L e p R b^{\mathrm{POA}}$ neurons, we injected adeno-associated virus expressing DREADD-Gq into the POA of Vglut $2^{\text {Cre }}$ $\left(V_{g l u t}{ }^{P O A}\right.$ DREADD-Gq) and $V_{g a t}{ }^{\mathrm{Cre}}$ (Vgat ${ }^{P O A}$ DREADD-Gq) mice. Subsequent $\mathrm{CNO}$ injection decreased core temperature in Vglut2 ${ }^{P O A}$ DREADD-Gq mice (Fig. 7G; repeated-measures ANOVA for the interaction between time and group: $F_{(6,42)}=$ 25.98, $p<0.001)$, but not in Vgat $^{P O A}$ DREADD-Gq mice (Fig. $7 H$; repeatedmeasures ANOVA for the interaction between time and group: $F_{(6,84)}=0.85, p>$ $0.05)$. Similarly, reduction in $\mathrm{VO}_{2}$ and postural extension were only observed in Vglut2 $2^{P O A}$ DREADD-Gq mice at RT (Fig. $8 A, D$; repeated-measures ANOVA for the effect of treatment during $6 \mathrm{~h}$ postinjection in $A: F_{(1,3)}=22.04, p<0.05$; in $D: F_{(1,3)}=3.79, p>0.05$; data not shown), suggesting that adaptations to warm temperature elicited by $\mathrm{LepRb}^{\mathrm{POA}}$ neurons are likely mediated by glutamatergic neurons. We further investigated whether ambient temperature challenges would reveal a role of GABAergic neurons in energy expenditure. However, also at cold and warm ambient temperature, CNO only decreased energy expenditure in $V g l u t 2^{P O A}$, but not in $\operatorname{Vgat}^{\mathrm{POA}}$, DREADD-Gq mice (Fig. $8 B, C, E, F$; repeated-measures ANOVA for the effect of treatment during $6 \mathrm{~h}$ postinjection in $B: F_{(1,3)}=55.33$, 
$p<0.01$; in $C: F_{(1,3)}=9.76, p=0.052$; in $E$ : $F_{(1,3)}=2.51, p>0.05$; in $F: F_{(1,3)}=0.037$, $p>0.05)$, further corroborating the finding that glutamatergic $\mathrm{POA}$ neurons regulate BAT thermogenesis, while GABAergic POA neurons play no obvious role in the control of energy expenditure. Furthermore, as observed with CNO-activated LepRb ${ }^{\text {POA }}$ neurons, pharmacogenetic activation of Vglut2 ${ }^{\mathrm{POA}}$ neurons showed the same ambient temperature-dependent changes in $\mathrm{VO}_{2}$ (Fig. 8G-I; repeated-measures ANOVA for the interaction between temperature and treatment in $G: F_{(2,6)}=8.73, p<0.05$; in $H$ : $F_{(2,6)}=1.88, p>0.05$; for the effect of temperature for $V g l u t 2^{P O A}$ DREADD-Gq in $I$ : $\left.F_{(2,6)}=8.73, p<0.05\right)$.

Locomotor activity of both $\mathrm{Vglut} 2^{\mathrm{POA}}$ and $V_{g a t}{ }^{P O A}$ DREADD-Gq mice was not significantly affected by $\mathrm{CNO}$ in any temperature condition (Fig. $8 \mathrm{~J}, \mathrm{~K}$; data not shown for 30 and $10^{\circ} \mathrm{C}$ ), which might explain the smaller reduction in core temperature and $\mathrm{VO}_{2}$ in $\operatorname{Vglut} 2^{\mathrm{POA}}$ DREADD-Gq mice compared with $L e p R b^{P O A}$ DREADD-Gq mice. However, CNO decreased RER similarly in $V_{g l u t} 2^{P O A}$ and $L e p R b^{P O A}$ DREADD-Gq mice but not in $\operatorname{Vgat}^{P O A}$ DREADD-Gq mice (data not shown).

\section{Discussion}

LepRb ${ }^{\text {POA }}$ neurons inhibit energy expenditure

Consistent with the overall role of POA neurons in thermoregulation, our data confirm that LepRb ${ }^{\text {POA }}$ neurons robustly modulate energy expenditure and body temperature and that this likely involves $\beta 3 \mathrm{AR}-$ dependent activation of BAT thermogenesis. Our data define a distinct population of glutamatergic LepRb ${ }^{\text {POA }}$ neurons that inhibit the sympathetic outflow to BAT and blunt adaptive thermogenesis. This is also in line with extensive studies in rats suggesting that POA neurons are mostly warm-sensitive and control cold or LPS-induced BAT thermogenesis (Morrison et al., 2014). Reduced BAT activity contributes to decreased energy expenditure and promotes weight gain, and the amount of BAT inversely correlates with the body mass index in humans (Cypess et al., 2009; van Marken Lichtenbelt et al., 2009). Therefore, our study contributes to a better understanding of how BAT activity is regulated for a potential therapeutic strategy to treat obesity.

We further speculate that LepRb ${ }^{\mathrm{POA}}$ neurons also modulate basal metabolic rate because pharmacogenetic activation of LepRb ${ }^{\mathrm{POA}}$ neurons still caused a significant decrease in energy expenditure at thermoneutrality $\left(30^{\circ} \mathrm{C}\right)$, at which adaptive thermogenesis does not contribute to energy expenditure (Cannon and Nedergaard, 2011), and CL316,243 was not able to block the

G
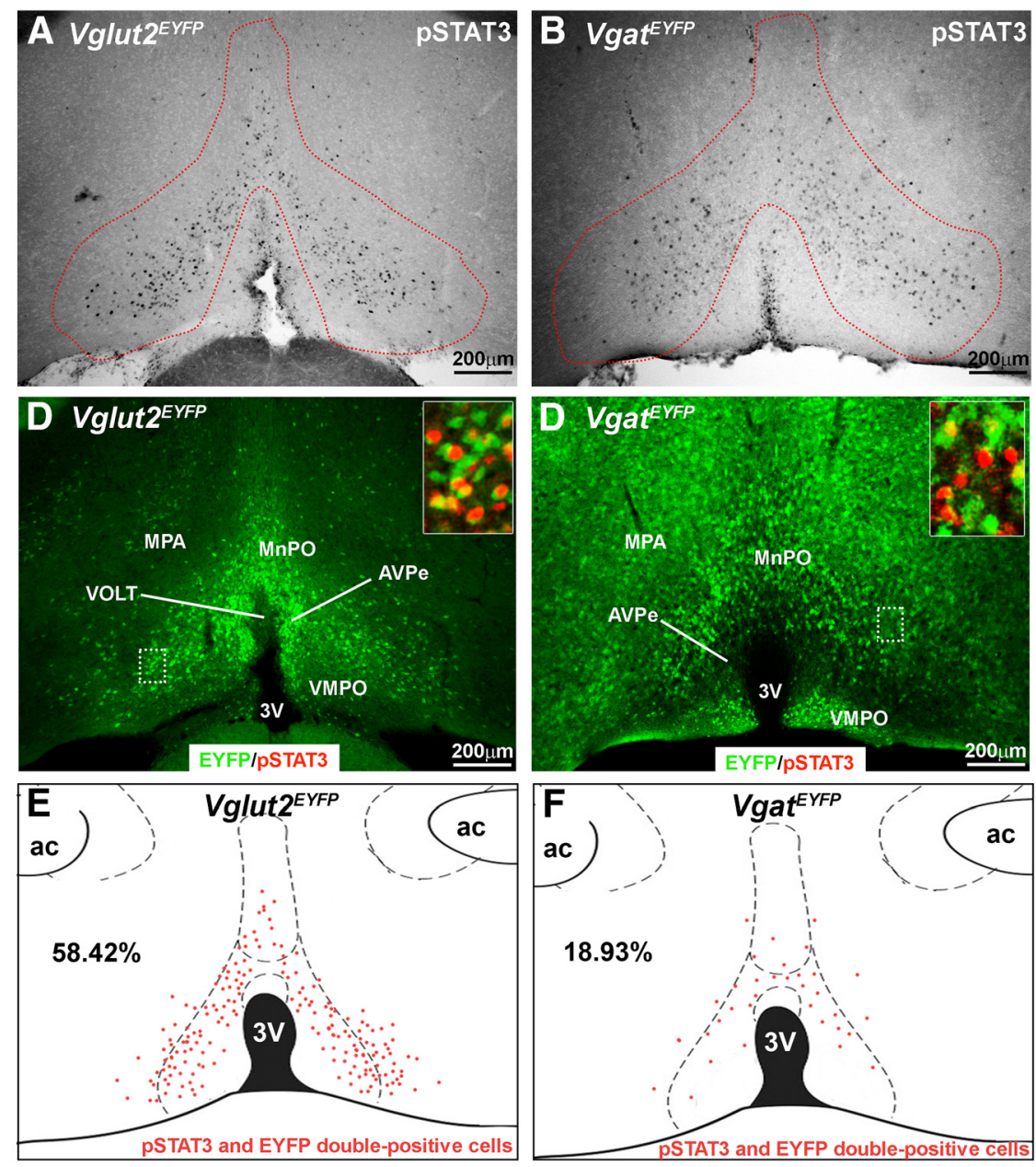

H
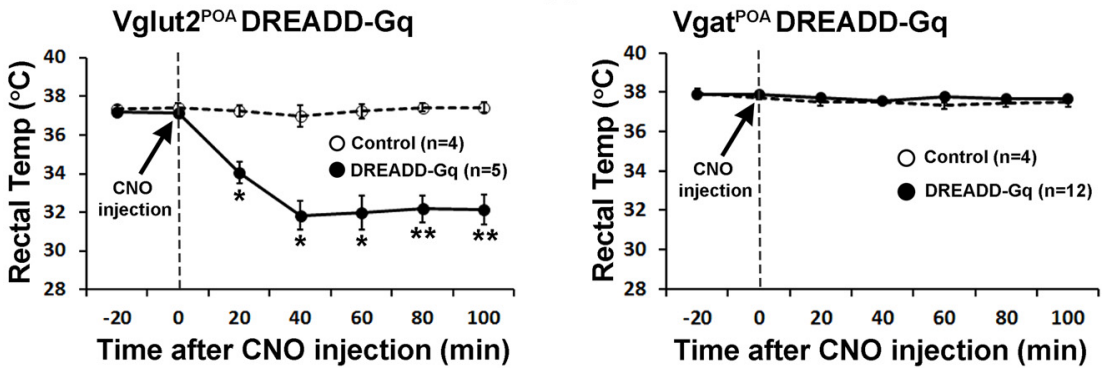

Figure 7. LepRb ${ }^{\mathrm{POA}}$ neurons are glutamatergic. $\boldsymbol{A}, \boldsymbol{B}$, Representative immunohistochemical images showing leptin-induced pSTAT3 (black, DAB staining) in the POA of $\operatorname{Vglut2}{ }^{E Y F P}(\boldsymbol{A}, n=3)$ and $\operatorname{Vgat}{ }^{\text {EYFP }}(\boldsymbol{B}, n=3)$ mice. Areas within dotted line indicate areas used for pSTAT3 cell counting. $\boldsymbol{C}, \boldsymbol{D}$, Representative immunohistochemical images showing leptin-induced PSTAT3 (red) and EYFP (green) in the POA of Vglut ${ }^{\text {EYFP }}(\boldsymbol{C})$ and $V g a t^{E Y F P}(\boldsymbol{D})$ mice. Insets show magnified images of the indicated areas (dotted-line boxes) to show colocalization of PSTAT3 and EYFP. $\boldsymbol{E}, \boldsymbol{F}$, Schematic drawings for the distribution of PSTAT3 and EYFP doublepositive cells in the POA in Vglut2 ${ }^{E Y F P}$ and Vgat ${ }^{E Y F P}$ mice. $\boldsymbol{G}, \boldsymbol{H}$, At RT, $C \mathrm{CN} 0$ injection $(1.5 \mathrm{mg} / \mathrm{kg}$, i.p.) decreased rectal temperature in Vglut2 ${ }^{P O A}$ DREADD-Gq but not in Vgat ${ }^{P O A}$ DREADD-Gq mice. Data are represented as mean \pm SEM. ${ }^{*} p<0.01$ and ${ }^{* *} p<0.001$ (two-way repeated-measures ANOVA and Bonferroni's pairwise comparisons).

full CNO effect on $\mathrm{VO}_{2}$ in $L e p R b^{P O A}$ DREADD-Gq mice. This additional suppression cannot be solely explained by decreased locomotor activity because activation of glutamatergic POA neurons in $V_{g l u t}{ }^{P O A}$ DREADD-Gq mice still reduced energy expenditure at $30^{\circ} \mathrm{C}$ in the absence of locomotor activity changes. In contrast to the highly regulated adaptive thermogenesis, basal metabolic rate is not subject to much variation, even though the thyroid hormone is one of the few modulators of basal metabolic rate (Kim, 2008). Indeed, temperature-sensitive POA neurons 
$<$ Vglut2 $^{\text {POA }}$ DREADD-Gq >

A

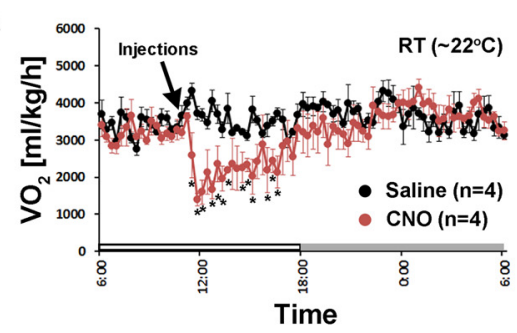

$<$ Vgat $^{\mathrm{POA}}$ DREADD-Gq >

D

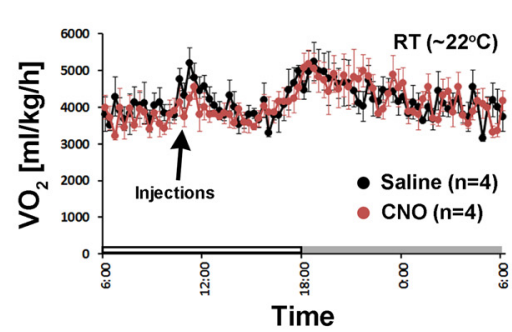

G

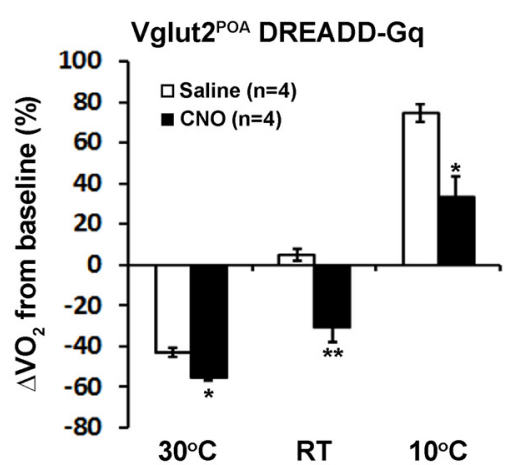

B

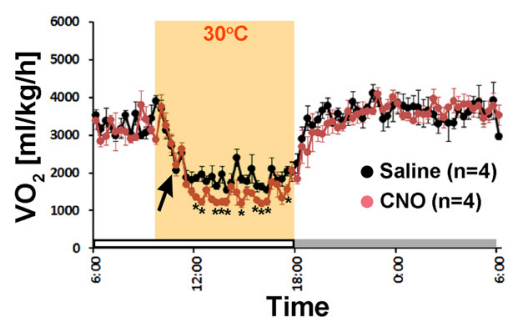

E

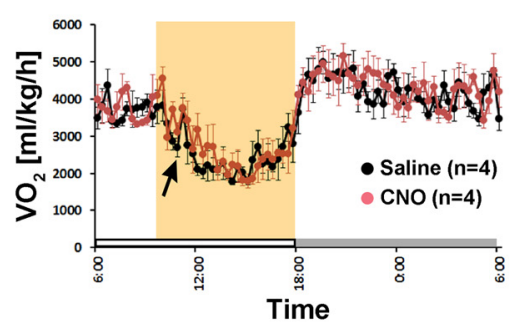

H

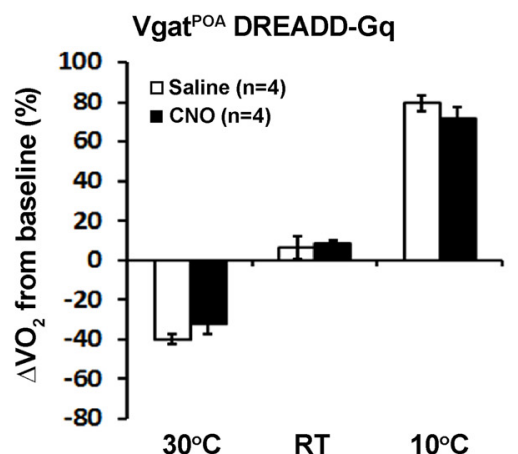

C

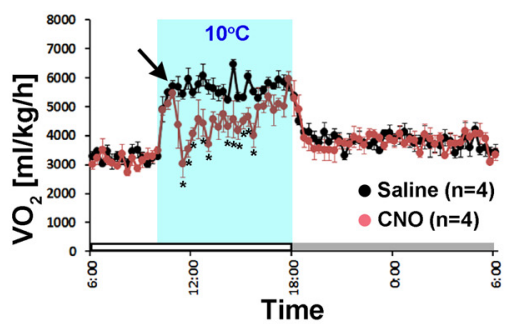

$\mathbf{F}$

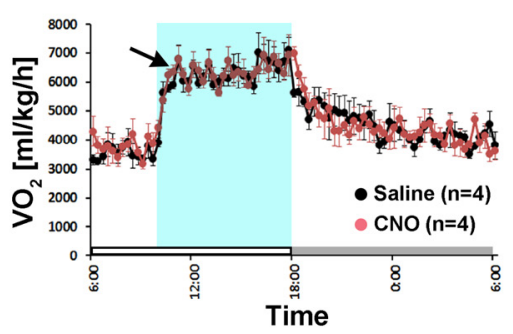

I

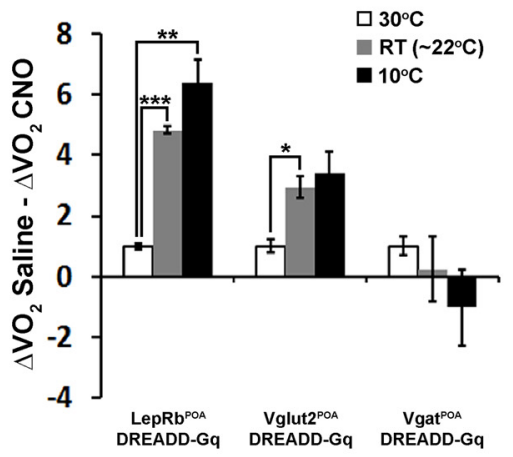

$\mathbf{J}$

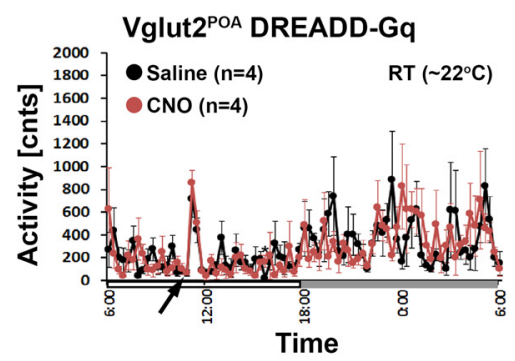

$\mathbf{K}$

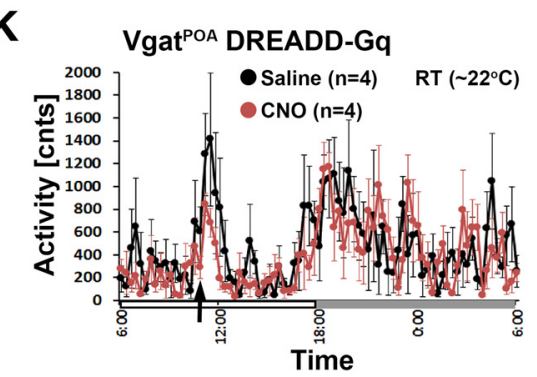

Figure 8. Glutamatergic, not GABAergic, POA neurons mediate adaptations to ambient temperature changes. $A-F, V_{2}$, was measured in $V g l u t 2^{P O A}$ and $V g a t^{P O A} D R E A D D-G q$ mice $\left(n=4\right.$ each) at RT, $30^{\circ} C$, and $10^{\circ} \mathrm{C}$. Saline (black) or CNO (0.5 mg/kg, i.p.; red) was injected at 11:00 A.M. (CT5, arrows; Fig. 6A). Orange and blue boxes indicate temperaturechange to 30 and $10^{\circ} \mathrm{C}$, respectively. 0 nly $V g /$ lut ${ }^{P O A}$ DREADD-Gq mice, but not $\mathrm{Vgat}{ }^{P O A} \mathrm{DREADD}-\mathrm{Gq}$ mice, further decreased $\mathrm{V}_{2}$ by $\mathrm{CNO}$ injection compared with saline injection in all temperature conditions. $G, H$, Average $\mathrm{V}_{2}$ during $4 \mathrm{~h}$ after injection was calculated and the change from baseline $\left(\Delta \mathrm{VO}_{2}\right)$ was compared between saline and $\mathrm{CNO}$ in each temperature condition. I, $\Delta \mathrm{VO}_{2}$ Saline $-\Delta \mathrm{VO}_{2} \mathrm{CNO}$ was calculated for each temperature condition and normalized to $30^{\circ} \mathrm{C}$. Data for LepRRPOA DREADD-Gq mice are from Figure 6E.J, $\boldsymbol{K}$, Locomotor activity in the same mice shown in $\boldsymbol{A}$ and $\boldsymbol{D}$ during the same period at RT. Locomotor activity was not affected by $C \mathrm{CNO}(0.5 \mathrm{mg} / \mathrm{kg}, \mathrm{i} . \mathrm{p}$.) in either Vglut $2^{P O A}(n=4)$ or Vgat ${ }^{P O A}(n=4)$ DREADD-Gq mice. Data are represented as mean \pm SEM. ${ }^{*} p<0.05,{ }^{* *} p<0.01$, and ${ }^{* * *} p<0.001$ (two-way repeated-measures ANOVA and Bonferroni's pairwise comparisons for $\boldsymbol{A}-\boldsymbol{H}, \boldsymbol{J}$, and $\boldsymbol{K}$, and one-way repeated-measures ANOVA and Fisher's least significant difference pairwise comparisons for $\boldsymbol{I}$ ).

regulate circulating thyroid-stimulating hormone levels and likely modulate thyroid-related changes in energy expenditure (Andersson et al., 1963; Martelli et al., 2014). Future studies will directly address whether and to what extent $\mathrm{LepRb}{ }^{\mathrm{POA}}$ neurons require the thyroid axis to modulate basal metabolic rate.

LepRb ${ }^{\text {POA }}$ neurons inhibit food intake and decrease body weight

Surprisingly, stimulation of LepRb ${ }^{\mathrm{POA}}$ neurons decreased body weight despite the robust hypometabolism and reduced locomo- tor activity, which is explained by the simultaneous decrease in food intake. We show here that the concurrent decrease in energy expenditure and food intake is a typical homeostatic adaptation to warm ambient temperature, which is meant to maintain constant body temperature and body weight. However, when warmsensing glutamatergic LepR ${ }^{\mathrm{POA}}$ neurons are activated in a nonthermoneutral environment (i.e., RT) to decrease energy expenditure and food intake as done in this study, body temperature and body weight are potently modulated as a result. Similarly, an adaptation to cold ambient temperature causes 
simultaneous increase in energy expenditure and food intake (Ravussin et al., 2014), and activation of cold-adaptive responses at warm temperature can be predicted to similarly modulate body temperature and weight.

We show that thermoneutral ambient temperature, but not cold temperature, strongly stimulates LepRb ${ }^{\text {POA }}$ neurons, suggesting that pharmacogenetic activation of LepRb ${ }^{\mathrm{POA}}$ neurons mimics the physiological and behavioral responses to warm/thermoneutral temperature exposure. Our data are consistent with studies showing that local warming of the POA reduces food intake (Andersson and Larsson, 1961) and that POA lesions disrupt proper food intake adjustment in response to changing ambient temperatures (Hamilton and Brobeck, 1964). Thus, our data support a major effect of LepRb ${ }^{\text {POA }}$ neurons on feeding. Interestingly, after cessation of chronic LepRb ${ }^{\text {POA }}$ neuronal stimulation, we did not observe compensatory overfeeding, which is typically observed after a state of negative energy balance, such as fasting or food restriction (Harris et al., 1986; Dulloo et al., 1997). This result suggests that the negative energy balance obtained by LepRb ${ }^{\mathrm{POA}}$ neuronal activation was not sensed as a physiological need state that requires compensation. It further argues against a physical locomotor limitation as a reason for the reduced food intake, which should have resulted in a compensatory overfeeding behavior once $\mathrm{CNO}$ injections were terminated.

Feeding behavior is centrally controlled by the hypothalamus. The arcuate nucleus (ARC) and the paraventricular nucleus of the hypothalamus (PVH) have been intensively studied for their potent effects on food intake, where orexigenic and anorexigenic neuronal populations and their neuropeptides mediate changes in food intake (Joly-Amado et al., 2014; Sutton et al., 2014; Münzberg and Morrison, 2015). It is unclear whether LepRb ${ }^{\mathrm{POA}}$ neurons modulate feeding by connecting with those known feeding circuits in the PVH or the ARC. The POA neurons were shown to innervate feeding behavior-related sites, such as the PVH, ventral tegmental area, and lateral hypothalamic area, but not the ARC or ventromedial nucleus of the hypothalamus (Swanson, 1976; Thompson and Swanson, 2003; McKinley et al., 2015). Future studies will specifically address how LepRb ${ }^{\mathrm{POA}}$ neurons mediate changes in food intake.

\section{A new view for homeostatic POA circuits}

POA neurons are mainly warm-sensing (Boulant and Dean, 1986 ), and in line with previous reports, we show that LepRb ${ }^{\text {POA }}$ neurons represent at least a subpopulation of warm-sensitive neurons. Several studies in rats show that temperature-sensing POA neurons innervate the DMH/DHA and $\mathrm{rRPa}$, which was recently confirmed in mice, in which LepRb ${ }^{\mathrm{POA}}$ neurons specif- ically innervate the DMH/DHA and rRPa (Zhang et al., 2011). The DMH/DHA is a key regulator of BAT thermogenesis (Zaretskaia et al., 2002, 2003; Cao et al., 2004; Madden and Morrison, 2004) and leptin maintains normal energy expenditure by directly stimulating DMH/DHA LepRb neurons (Enriori et al., 2011; Zhang et al., 2011; Rezai-Zadeh et al., 2014).

POA warm-sensitive neurons are proposed as predominantly GABAergic neurons that are inhibited by cold exposure or febrile stimuli, which results in the disinhibition of their target neurons in the DMH/DHA and rRPa (Morrison et al., 2014). In our study, pharmacogenetic activation of GABAergic Vgat ${ }^{\mathrm{POA}}$ neurons had no effect on thermoregulatory responses, contradicting previous reports. The exact reasons for this discrepancy are unclear but several possibilities can be postulated. First, DREADD-Gq virus injections may not have optimally targeted warm-sensing GABAergic POA neurons. Second, species-specific difference or different experimental conditions may have contributed to inconsistent results. Most previous studies were conducted in anesthetized rats in which cooling or febrile responses were altered with chemical drugs to modulate neuronal activity, without direct manipulation of GABA or glutamatergic neurons. In contrast, our studies are the first to test the activation of genetically defined neuronal subpopulations at different ambient tempera- 
tures in freely moving mice. Third, separate GABAergic neurons may represent cold-sensitive and warm-sensitive neurons in the POA (Nakamura and Morrison, 2008), and stimulating both populations simultaneously may offset each other's function.

In any case, our data make a strong case that DMH/DHAprojecting and $\mathrm{RPa}$-projecting LepRb ${ }^{\mathrm{POA}}$ neurons are mainly glutamatergic and robustly modulate energy expenditure and food intake in mice, even though it should be noted that activation of glutamatergic POA neurons also includes non-LepRb ${ }^{\text {POA }}$ neurons that may have contributed to the modulation of energy expenditure. Consequently, our data argue against a direct stimulation of BAT-activating LepRb $\mathrm{b}^{\mathrm{DMH} / \mathrm{DHA}}$ or RPa neurons by LepRb $^{\text {POA }}$ neurons (Cao et al., 2004; Cao and Morrison, 2006; Nakamura and Morrison, 2007; Rezai-Zadeh et al., 2014). Therefore, we propose a new view for the neurochemical and functional properties of BAT-related POA circuits (Fig. 9). Here, glutamatergic LepRb ${ }^{\mathrm{POA}}$ neurons are stimulated by warm ambient temperature and communicate this stimulatory signal to the DMH/DHA and RPa. For example, warm-sensitive cholinergic neurons in the DMH decrease energy expenditure by inhibiting rRPa neurons (Jeong et al., 2015). Thus, LepRb ${ }^{\text {POA }}$ neurons may directly innervate these neurons, and future studies will have to identify which LepRb ${ }^{\text {POA }}$ neuronal targets mediate the observed warm-adaptive responses. Most importantly, LepRb ${ }^{\mathrm{POA}}$ neurons regulate energy expenditure and food intake, and are critical for maintaining homeostasis for body weight and body temperature.

\section{References}

Andersson B, Larsson B (1961) Influence of local temperature changes in the preoptic area and rostral hypothalamus on the regulation of food and water intake. Acta Physiol Scand 52:75-89. CrossRef Medline

Andersson B, Ekman L, Gale CC, Sundsten JW (1963) Control of thyrotrophic hormone (Tsh) secretion by the "heat loss center." Acta Physiol Scand 59:12-33. CrossRef Medline

Bellefontaine N, Chachlaki K, Parkash J, Vanacker C, Colledge W, d'Anglemont de Tassigny X, Garthwaite J, Bouret SG, Prevot V (2014) Leptin-dependent neuronal NO signaling in the preoptic hypothalamus facilitates reproduction. J Clin Invest 124:2550-2559. CrossRef Medline

Boulant JA, Dean JB (1986) Temperature receptors in the central nervous system. Annu Rev Physiol 48:639-654. CrossRef Medline

Cannon B, Nedergaard J (2011) Nonshivering thermogenesis and its adequate measurement in metabolic studies. J Exp Biol 214:242-253. CrossRef Medline

Cao WH, Morrison SF (2006) Glutamate receptors in the raphe pallidus mediate brown adipose tissue thermogenesis evoked by activation of dorsomedial hypothalamic neurons. Neuropharmacology 51:426-437. CrossRef Medline

Cao WH, Fan W, Morrison SF (2004) Medullary pathways mediating specific sympathetic responses to activation of dorsomedial hypothalamus. Neuroscience 126:229-240. CrossRef Medline

Collins S, Yehuda-Shnaidman E, Wang H (2010) Positive and negative control of Ucpl gene transcription and the role of $\beta$-adrenergic signaling networks. Int J Obes (Lond) 34 [Suppl 1]:S28-S33. CrossRef Medline

Cypess AM, Lehman S, Williams G, Tal I, Rodman D, Goldfine AB, Kuo FC, Palmer EL, Tseng YH, Doria A, Kolodny GM, Kahn CR (2009) Identification and importance of brown adipose tissue in adult humans. $\mathrm{N}$ Engl J Med 360:1509-1517. CrossRef Medline

Dulloo AG, Jacquet J, Girardier L (1997) Poststarvation hyperphagia and body fat overshooting in humans: a role for feedback signals from lean and fat tissues. Am J Clin Nutr 65:717-723. Medline

Enriori PJ, Sinnayah P, Simonds SE, Garcia Rudaz C, Cowley MA (2011) Leptin action in the dorsomedial hypothalamus increases sympathetic tone to brown adipose tissue in spite of systemic leptin resistance. J Neurosci 31:12189-12197. CrossRef Medline

Faouzi M, Leshan R, Björnholm M, Hennessey T, Jones J, Münzberg H (2007) Differential accessibility of circulating leptin to individual hypothalamic sites. Endocrinology 148:5414-5423. CrossRef Medline

Gao Q, Horvath TL (2007) Neurobiology of feeding and energy expenditure. Annu Rev Neurosci 30:367-398. CrossRef Medline
Grujic D, Susulic VS, Harper ME, Himms-Hagen J, Cunningham BA, Corkey BE, Lowell BB (1997) Beta3-adrenergic receptors on white and brown adipocytes mediate beta3-selective agonist-induced effects on energy expenditure, insulin secretion, and food intake. A study using transgenic and gene knockout mice. J Biol Chem 272:17686-17693. CrossRef Medline

Hamilton CL, Brobeck JR (1964) Food intake and temperature regulation in rats with rostral hypothalamic lesions. Am J Physiol 207:291-297. Medline

Harris RB, Kasser TR, Martin RJ (1986) Dynamics of recovery of body composition after overfeeding, food restriction or starvation of mature female rats. J Nutr 116:2536-2546. Medline

Haynes WG, Morgan DA, Walsh SA, Mark AL, Sivitz WI (1997) Receptormediated regional sympathetic nerve activation by leptin. J Clin Invest 100:270-278. CrossRef Medline

Jeong JH, Lee DK, Blouet C, Ruiz HH, Buettner C, Chua S Jr, Schwartz GJ, Jo YH (2015) Cholinergic neurons in the dorsomedial hypothalamus regulate mouse brown adipose tissue metabolism. Mol Metab 4:483-492. CrossRef Medline

Joly-Amado A, Cansell C, Denis RG, Delbes AS, Castel J, Martinez S, Luquet S (2014) The hypothalamic arcuate nucleus and the control of peripheral substrates. Best Pract Res Clin Endocrinol Metab 28:725-737. CrossRef Medline

Kim B (2008) Thyroid hormone as a determinant of energy expenditure and the basal metabolic rate. Thyroid 18:141-144. CrossRef Medline

Laque A, Yu S, Qualls-Creekmore E, Gettys S, Schwartzenburg C, Bui K, Rhodes C, Berthoud HR, Morrison CD, Richards BK, Münzberg H (2015) Leptin modulates nutrient reward via inhibitory galanin action on orexin neurons. Mol Metab 4:706-717. CrossRef Medline

Leshan RL, Bjornholm M, Munzberg H, Myers MG Jr (2006) Leptin receptor signaling and action in the central nervous system. Obesity (Silver Spring) 14 [Suppl 5]:208S-212S. Medline

Leshan RL, Opland DM, Louis GW, Leinninger GM, Patterson CM, Rhodes CJ, Münzberg H, Myers MG Jr (2010) Ventral tegmental area leptin receptor neurons specifically project to and regulate cocaine- and amphetamine-regulated transcript neurons of the extended central amygdala. J Neurosci 30:5713-5723. CrossRef Medline

Madden CJ, Morrison SF (2004) Excitatory amino acid receptors in the dorsomedial hypothalamus mediate prostaglandin-evoked thermogenesis in brown adipose tissue. Am J Physiol Regul Integr Comp Physiol 286: R320-R325. Medline

Martelli D, Luppi M, Cerri M, Tupone D, Mastrotto M, Perez E, Zamboni G, Amici R (2014) The direct cooling of the preoptic-hypothalamic area elicits the release of thyroid stimulating hormone during wakefulness but not during REM sleep. PLoS One 9:e87793. CrossRef Medline

McKinley MJ, Yao ST, Uschakov A, McAllen RM, Rundgren M, Martelli D (2015) The median preoptic nucleus: front and centre for the regulation of body fluid, sodium, temperature, sleep and cardiovascular homeostasis. Acta Physiol (Oxf) 214:8-32. CrossRef Medline

Morrison SF, Madden CJ, Tupone D (2014) Central neural regulation of brown adipose tissue thermogenesis and energy expenditure. Cell Metab 19:741-756. CrossRef Medline

Münzberg H, Morrison CD (2015) Structure, production and signaling of leptin. Metabolism 64:13-23. CrossRef Medline

Nakamura K (2011) Central circuitries for body temperature regulation and fever. Am J Physiol Regul Integr Comp Physiol 301:R1207-R1228. CrossRef Medline

Nakamura K, Morrison SF (2007) Central efferent pathways mediating skin cooling-evoked sympathetic thermogenesis in brown adipose tissue. Am J Physiol Regul Integr Comp Physiol 292:R127-R136. Medline

Nakamura K, Morrison SF (2008) Preoptic mechanism for cold-defensive responses to skin cooling. J Physiol 586:2611-2620. CrossRef Medline

Nakamura K, Matsumura K, Kaneko T, Kobayashi S, Katoh H, Negishi M (2002) The rostral raphe pallidus nucleus mediates pyrogenic transmission from the preoptic area. J Neurosci 22:4600-4610. Medline

Nakamura Y, Nakamura K, Matsumura K, Kobayashi S, Kaneko T, Morrison SF (2005) Direct pyrogenic input from prostaglandin EP3 receptorexpressing preoptic neurons to the dorsomedial hypothalamus. Eur J Neurosci 22:3137-3146. CrossRef Medline

Nakamura Y, Nakamura K, Morrison SF (2009) Different populations of prostaglandin EP3 receptor-expressing preoptic neurons project to two fever-mediating sympathoexcitatory brain regions. Neuroscience 161: 614-620. CrossRef Medline 
Paxinos G, Franklin KB (2004) The mouse brain in stereotaxic coordinates, compact 2nd ed. Boston: Elsevier Academic.

Ravussin Y, Xiao C, Gavrilova O, Reitman ML (2014) Effect of intermittent cold exposure on brown fat activation, obesity, and energy homeostasis in mice. PLoS One 9:e85876. CrossRef Medline

Rezai-Zadeh K, Yu S, Jiang Y, Laque A, Schwartzenburg C, Morrison CD, Derbenev AV, Zsombok A, Münzberg H (2014) Leptin receptor neurons in the dorsomedial hypothalamus are key regulators of energy expenditure and body weight, but not food intake. Mol Metab 3:681-693. CrossRef Medline

Roberts WW (1988) Differential thermosensor control of thermoregulatory grooming, locomotion, and relaxed postural extension. Ann N Y Acad Sci 525:363-374. CrossRef Medline

Rosenbaum M, Leibel RL (2010) Adaptive thermogenesis in humans. Int J Obes (Lond) 34 [Suppl 1]:S47-S55. CrossRef Medline

Susulic VS, Frederich RC, Lawitts J, Tozzo E, Kahn BB, Harper ME, HimmsHagen J, Flier JS, Lowell BB (1995) Targeted disruption of the beta 3-adrenergic receptor gene. J Biol Chem 270:29483-29492. CrossRef Medline

Sutton AK, Pei H, Burnett KH, Myers MG Jr, Rhodes CJ, Olson DP (2014) Control of food intake and energy expenditure by Nos1 neurons of the paraventricular hypothalamus. J Neurosci 34:15306-15318. CrossRef Medline

Swanson LW (1976) An autoradiographic study of the efferent connections of the preoptic region in the rat. J Comp Neurol 167:227-256. CrossRef Medline

Thompson RH, Swanson LW (2003) Structural characterization of a hypothalamic visceromotor pattern generator network. Brain Res Rev 41: 153-202. CrossRef Medline

Trayhurn P, Thurlby PL, James WP (1977) Thermogenic defect in preobese ob/ob mice. Nature 266:60-62. CrossRef Medline van Marken Lichtenbelt WD, Vanhommerig JW, Smulders NM, Drossaerts JM, Kemerink GJ, Bouvy ND, Schrauwen P, Teule GJ (2009) Coldactivated brown adipose tissue in healthy men. N Engl J Med 360: 1500-1508. CrossRef Medline

Vong L, Ye C, Yang Z, Choi B, Chua S Jr, Lowell BB (2011) Leptin action on GABAergic neurons prevents obesity and reduces inhibitory tone to POMC neurons. Neuron 71:142-154. CrossRef Medline

Xiao C, Goldgof M, Gavrilova O, Reitman ML (2015) Anti-obesity and metabolic efficacy of the beta3-adrenergic agonist, CL316243, in mice at thermoneutrality compared to 22 degrees C. Obesity (Silver Spring) 23 : 1450-1459. CrossRef Medline

Xu Y, Kim ER, Zhao R, Myers MG Jr, Munzberg H, Tong Q (2013) Glutamate release mediates leptin action on energy expenditure. Mol Metab 2:109-115. CrossRef Medline

Yoshida K, Li X, Cano G, Lazarus M, Saper CB (2009) Parallel preoptic pathways for thermoregulation. J Neurosci 29:11954-11964. CrossRef Medline

Zaretskaia MV, Zaretsky DV, Shekhar A, DiMicco JA (2002) Chemical stimulation of the dorsomedial hypothalamus evokes non-shivering thermogenesis in anesthetized rats. Brain Res 928:113-125. CrossRef Medline

Zaretskaia MV, Zaretsky DV, DiMicco JA (2003) Role of the dorsomedial hypothalamus in thermogenesis and tachycardia caused by microinjection of prostaglandin E2 into the preoptic area in anesthetized rats. Neurosci Lett 340:1-4. CrossRef Medline

Zhang Y, Kerman IA, Laque A, Nguyen P, Faouzi M, Louis GW, Jones JC, Rhodes C, Münzberg H (2011) Leptin-receptor-expressing neurons in the dorsomedial hypothalamus and median preoptic area regulate sympathetic brown adipose tissue circuits. J Neurosci 31:1873-1884. CrossRef Medline 